\title{
Microstructures and petrology of melt inclusions in the anatectic sequence of Jubrique (Betic Cordillera, S Spain) Implications for crustal anatexis
}

\section{Journal Article}

\section{Author(s):}

Barich, Amel; Acosta-Vigil, Antonio; Garrido, Carlos J.; Cesare, Bernardo; Tajčmanová, Lucie; Bartoli, Omar

Publication date:

2014-10

\section{Permanent link:}

https://doi.org/10.3929/ethz-a-010735965

\section{Rights / license:}

In Copyright - Non-Commercial Use Permitted

Originally published in:

Lithos 206, https://doi.org/10.1016/j.lithos.2014.08.003

Funding acknowledgement:

335577 - Interplay between metamorphism and deformation in the Earth's lithosphere (EC) 


\section{Microstructures and petrology of melt inclusions in the anatectic}

2 sequence of Jubrique (Betic Cordillera, S Spain): implications for crustal anatexis

4 Amel Barich ${ }^{\mathrm{a}}$, Antonio Acosta-Vigil ${ }^{\mathrm{a},{ }^{*}}$, Carlos J. Garrido ${ }^{\mathrm{a}}$, Bernardo Cesare ${ }^{\mathrm{b}}$, Lucie

5 Tajčmanovác, Omar Bartoli ${ }^{\mathrm{b}}$

6 a Instituto Andaluz de Ciencias de la Tierra, Consejo Superior de Investigaciones Científicas-Universidad

7 de Granada, Avenida de las Palmeras 4, 18100 Armilla, Granada, Spain

$8 \quad{ }^{\mathrm{b}}$ Dipartimento di Geoscienze, Università di Padova, Padova, Italy

$9{ }^{\mathrm{c}}$ Department of Earth Sciences, Swiss Federal Institute of Technology, Zurich, Switzerland

10 * Corresponding author. Tel.: +34 958230000 ext. 190033; fax: +34 958552620.

11 E-mail address: $\underline{\text { aacosta@ugr.es (A. Acosta-Vigil) }}$

\section{Abstract}

13 We report a new occurrence of melt inclusions in polymetamorphic granulitic gneisses 14 of the Jubrique unit, a complete though strongly thinned crustal section located above 15 the Ronda peridotite slab (Betic Cordillera, S Spain). The gneissic sequence is 16 composed of mylonitic gneisses at the bottom and in contact with the peridotites, and 17 porphyroblastic gneisses on top. Mylonitic gneisses are strongly deformed rocks with abundant garnet and rare biotite. Except for the presence of melt inclusions, microstructures indicating the former presence of melt are rare or absent. Upwards in the sequence garnet decreases whereas biotite increases in modal proportion. Melt inclusions are present from cores to rims of garnets throughout the entire sequence. Most of the former melt inclusions are now totally crystallized and correspond to nanogranites, whereas some of them are partially made of glass or, more rarely, are totally glassy. They show negative crystal shapes and range in size from $\approx 5$ to 200 micrometers, with a mean size of $\approx 30-40$ micrometers. Daughter phases in nanogranites and partially crystallized melt inclusions include quartz, feldspars, biotite and muscovite; accidental minerals include kyanite, graphite, zircon, monazite, rutile and ilmenite; glass has a granitic composition. Melt inclusions are mostly similar throughout all the gneissic sequence. Some fluid inclusions, of possible primary origin, are spatially associated with melt inclusions, indicating that at some point during the suprasolidus history of these rocks granitic melt and fluid coexisted. Thermodynamic modeling and conventional thermobarometry of mylonitic gneisses provide peak conditions of $\approx 850$ 
${ }^{\circ} \mathrm{C}$ and 12-14 kbar, corresponding to cores of large garnets with inclusions of kyanite and rutile. Post-peak conditions of $\approx 800-850{ }^{\circ} \mathrm{C}$ and $5-6$ kbar are represented by rim regions of large garnets with inclusions of sillimanite and ilmenite, cordierite-quartzbiotite coronas replacing garnet rims, and the matrix with oriented sillimanite. Previous conventional petrologic studies on these strongly deformed rocks have proposed that anatexis started during decompression from peak to post-peak conditions and in the field of sillimanite. The study of melt inclusions shows, however, that melt was already present in the system at peak conditions, and that most garnet grew in the presence of melt.

Keywords: Melt inclusions, crustal anatexis, kyanite, Ronda peridotites, Betic Cordillera

\section{Introduction}

Melt inclusions (MI) are small droplets of liquid, commonly a few to tens of micrometers across, trapped by minerals that grow in the presence of melt. They were first described by Sorby (1858) in igneous rocks, where they constitute a wealth of information on melt chemistry (e.g. Webster et al., 1997; Gurenko et al., 2005; Wanless et al., 2014). Many of the assumptions concerning the interpretation of fluid inclusions (FI) have been applied to MI (Sorby, 1958; Roedder, 1984; Bodnar and Student, 2006). More recently, MI have also been reported in crustal crystalline rocks (Cesare et al., 1997; Hwang et al., 2001; Stöckhert et al., 2001). Most melting reactions during crustal anatexis are incongruent (e.g. Clemens, 2006), i.e. produce melt and peritectic minerals, providing the opportunity that these minerals trap inclusions of the coexisting silicate liquid. Hence, MI trapped during melting can supply the composition of the primary anatectic melt (Cesare et al., 2009; 2011), in contrast with MI trapped during crystallization of cooling igneous rocks that provide the composition of fractionated (as opposed to primary) melts (Webster et al., 1997; Thomas and Davidson, 2013; see also discussion in Bartoli et al., 2014).

Most MI in anatectic terranes appear partially or totally crystallized due to slow cooling at depth. Owing to the granitic phase assemblage made of micron to submicron quartz, feldspars and micas, crystallized MI have been named "nanogranites" (Cesare et al., 2009). With the recent development of in-situ and high spatial resolution microanalytical techniques, as well as appropriate methods to remelt and rehomogenize nanogranites (Bartoli et al., 2013a, 2014), it is possible to characterize precisely MI, in order to relate their information to the process of anatexis of the host rock. Hence MI 
represent a new and powerful method to study anatexis, primarily because they can provide information on the parental melt compositions produced at the source region of crustal granites, including concentrations of $\mathrm{H}_{2} \mathrm{O}$ and fluid regimes (Cesare et al., 2011; Ferrero et al., 2012; Bartoli et al., 2013b, 2014). This information can complement, and in some cases be more precise, than that provided by classical petrological and geochemical studies of anatectic terrains, for instance regarding the composition of the primary anatectic melt, which has been traditionally approximated by the composition of anatectic leucosomes. This is particularly important in cases where deformation has partially or totally erased the primary anatectic macro- and micro-structures. In these cases, the presence of MI may be the only evidence remaining in the rock for the presence and nature of melt (Cesare et al., 2011).

The number of MI occurrences in anatectic terranes reported in the literature is quite modest and, among those cases, only a few provide bulk compositional data from the MI (Cesare et al., 2011; Ferrero et al., 2012; Bartoli et al., 2013b). This is due to the relatively recent discovery of MI in crustal anatectic rocks (Cesare et al., 1997, 2009, 2011; Hwang et al., 2001; Stöckhert et al., 2001, 2009; Korsakov and Hermann, 2006; Gao et al., 2012; Darling, 2013; Liu et al., 2013) and, more importantly, the very recent development of appropriate methodologies to recover the information encrypted within these former droplets of melt (Malaspina et al., 2006; Perchuck et al., 2008; Bartoli et al., 2013a, 2013b, 2014).

We report the presence and microstructures of MI in metasedimentary granulitefacies gneisses of the Jubrique unit, located in contact, and structurally above, the Ronda peridotite slab, in the hinterland of the Betic Cordillera (S Spain). Jubrique constitutes a complete though strongly thinned section $(\leq 5 \mathrm{~km})$ of upper to middlelower continental crust. The studied gneisses, located at the bottom of the sequence, are strongly deformed and show a complex polymetamorphic history (Loomis, 1972; Torres-Roldán, 1981). Hence, Jubrique provides an exceptional opportunity to study partial melting in complex regional polymetamorphic and strongly deformed rocks by using the new approach of the MI (Cesare et al., 2009, 2011). In addition, crustal anatexis is a fundamental process that controls the differentiation of the continental crust (Sawyer et al., 2011), and this quite continuous section of continental crust offers the opportunity to characterize partial melting of middle-to-lower crustal levels, and study its potential effects on the compositional segregation of the crust. We start in this contribution by describing in detail the microstructures and phase assemblages of the 
100 MI present throughout the entire sequence of gneisses, and discuss their bearing on the 101 process of partial melting of the gneisses. The fundamental aims of this study consist of:

102 (i) describing a new occurrence of MI in the granulitic gneisses of Jubrique, and their microstructural evolution along the prograde metamorphic sequence; and (ii) to shed light on the timing and nature of the anatectic processes that affected these strongly deformed and polymetamorphic rocks.

\section{Geological setting}

107 The Betic Cordillera in southern Spain and the Rif in northern Morocco constitute an arcuate orogen formed during the N-S collision between Eurasian and African plates and the westward migration of the Alborán lithospheric domain, from Early-Middle

110 Eocene to Early Miocene times (Fig. 1) (Andrieux et al., 1971; Dewey et al., 1989; Platt 111 et al., 2013). The Alborán domain represents the hinterland of this orogen, and is 112 formed by a complex stack of nappes made of mostly supracrustal metamorphic rocks.

113 Based on lithostratigraphic and metamorphic criteria, these nappes have been grouped 114 into two major tectonic complexes which, in the Betic Cordillera, correspond to the 115 Maláguide, on top, and the Alpujárride, at the bottom. In the highest-grade metamorphic 116 areas of the Betics, the Alpujárride unit of Jubrique incorporates at its base a tectonic 117 slab of subcontinental mantle peridotites, the Ronda peridotites (Lundeen, 1978; Obata, 118 1980; Tubía and Cuevas, 1986; Balanyá et al., 1997; Lenoir et al., 2001; Garrido et al., 119 2011).

120 The rocks studied in this contribution are granulite-facies gneisses pertaining to the 121 Jubrique unit. This unit constitutes a complete though strongly thinned section $(\leq 5 \mathrm{~km})$ 122 of upper to middle-lower continental crust, ranging from carbonates and low-grade 123 phyllites at the top, to schists towards the middle, and to garnet-bearing gneisses at the bottom (Fig. 1). Rocks are affected by a penetrative foliation parallel to the lithological contacts. The gneisses are in contact with the underlying Ronda peridotites through a high temperature ductile shear zone; this contact is parallel to the mylonitic foliation of

127 the crustal rocks. The peridotites constitute a slab of subcontinental mantle up to $5 \mathrm{~km}$ 128 thick (Ludeen, 1978; Balanyá et al., 1997). Carbonates and phyllites are Permo-Triassic 129 and were deformed and metamorphosed during the Alpine orogeny. Schist and gneisses 130 are pre-Carboniferous and represent a polymetamorphic basement affected by at least the Variscan and Alpine orogenies. Rocks from all levels in the crustal section seem to record nearly isothermal decompression paths, from $14-12 \mathrm{~kb}$ to $4 \mathrm{~kb}$ at $750-800{ }^{\circ} \mathrm{C}$ in 
133 the case of the gneisses located at the contact with the Ronda peridotites. The HP-HT 134 event has been related to the thickening of the Alborán domain. The main foliation in 135 the rocks postdate HP-HT assemblages and predate LP-HT minerals, and hence has

136 been associated with the ductile thinning of the sequence. In this interpretation, Jubrique 137 would represent a thinned and stretched remain of the Alpine collisional thickened crust 138 (Torres-Roldán, 1981; Balanyá et al., 1997; Argles et al., 1999; Platt et al., 2003). The 139 gneisses located at the bottom of the crustal sequence and in contact with the 140 peridotites, were above their solidus during part of the metamorphic evolution. Previous 141 studies have concluded that partial melting occurred during decompression and in the 142 field of sillimanite (Platt et al., 2003). Recent studies of gneisses of apparently similar 143 composition and structural position in the Rif have described the presence of diamond 144 and coesite included in garnet, suggesting UHP conditions of 6-7 GPa at $\mathrm{T}>1100^{\circ} \mathrm{C}$ 145 (Ruiz-Cruz and Sanz de Galdeano, 2012, 2013).

\section{3. Analytical methods}

147 The minimum amount of material collected in the field for chemical analyses was 148 about 8 to $10 \mathrm{~kg}$ per sample. Powders with a grain size $\leq 25 \mu \mathrm{m}$ were obtained by 149 crushing and milling the samples using a crusher with hardened still jaws and an agate 150 ring mill, respectively. Bulk rock major element analyses were conducted by X-Ray 151 fluorescence spectrometry at the Instituto Andaluz de Ciencias de la Tierra (CSIC, 152 Universidad de Granada), using a Bruker AXS S4 Pioneer instrument. The analyses 153 were done on glass beads made by fusing the rock powder mixed with $\mathrm{Li}_{2} \mathrm{~B}_{4} \mathrm{O}_{7}$. The 154 analytical detection limit and instrumental error were $0.1 \%$ and $<1 \%$, respectively.

155 Microstructrures of MI were characterized using conventional microscope 156 petrography and a QUANTA 400 environmental scanning electron microscope at the 157 Centro de Instrumentación Científica (CIC), Universidad de Granada, equiped with 158 EDAX EDS (ultrathin window) and $\mathrm{Li}(\mathrm{Si})$ detectors. Mineral compositions were 159 determined using a Cameca SX100 electron microprobe at the CIC. Natural and 160 synthetic silicate oxides were used for calibration and ZAF correction was applied.

\section{4. Sampling, petrography and composition of minerals}

162 Most of the previous petrologic studies have divided the gneissic sequence of 163 Jubrique into two major gneiss types, based either on the structures or mineral 164 assemblages. Although structures, mineralogy and microstructures indicate that these 
rocks represent anatectic migmatites (see below), we have maintained the previous terminology of gneisses though have also provided the corresponding migmatitic terms. We have used field and petrographic criteria to distinguish two types of gneisses as well: (i) mylonitic gneisses at the bottom of the sequence and in contact with the underlying Ronda peridotites, and (ii) porphyroblastic gneisses on top of the mylonitic gneisses and right below the schists. Mylonitic gneisses constitute $\mathrm{a} \approx 300-500 \mathrm{~m}$-thick sequence of rocks that, at the outcrop scale, appear as dark, Grt-rich rocks and rather massive rocks, except for the presence of frequent mm-to-cm Grt-bearing leucocratic bands that define a foliation and provides the rock with the appearance of a stromatic metatexitic migmatite (Fig. 2a-b; see Sawyer, 2008) (mineral abbreviations are after Whitney and Evans, 2010; except for silicate melt, Liq). This foliation is parallel to the contact with the peridotites. Leucocratic bands or leucosomes may occasionally reach up to several tens of $\mathrm{cm}$ in thickness and constitute tabular concordant Grt-rich leucocratic bodies (Fig. 2c); in this case, a foliation parallel to that affecting the host rock is clearly visible in the leucocratic bands at the outcrop scale. Some domains of the mylonitic gneisses are less affected by the deformation that produced the stromatic appearance, and appear to record a previous stage in the history of the rock, characterized by a dilatant structure (Fig. 2a; Saywer, 2008). In these domains the proportion of leucosomes increases, appearing as mm-to-cm layers roughly parallel to the foliation, but also as veins or pods perpendicular to the foliation (Figs. 2a). These observations suggest that some melt has escaped from this rock during deformation and development of the stromatic migmatite. Garnet is always present within all the described leucocratic bands, veins and pods. However, there are also thin Grt-absent and Bt-Crd-bearing leucocratic dikes crosscutting the foliation at high angle, that in contrast with previously described Grt-bearing bands and veins, seem to develop under ductile-to-fragile conditions (Figs. 2a, 2d). The mylonitic gneisses are equivalent to the lower part of the gneiss series described by Loomis (1972), rocks belonging to the lower part of the Grt-Ky-Kfs zone of Torres-Roldán (1981), or the garnet gneiss of Platt et al. (2003). Upper in the sequence and further away from the contact with the peridotites, porphyroblastic gneisses are lighter, coarser-grained and more heterogeneous rocks, showing a clear layering defined by alternating mm-to-dm leucocratic and mesocratic-to-melanocratic bands (Fig. 2e-g). These bands are parallel to the mylonitic foliation of the underlying gneisses. Compared with the mylonitic gneisses, Grt decreases whereas Bt increases in abundance (Fig. 3). Biotite is aligned 
and defines a schistosity parallel to the banding of the rock. Based on the structure, these rocks can be classified as stromatric metatexites (Figs. 2e-f) or schlieric diatexites (Fig. 2g). Leucocratic bands or leucosomes contain Grt and are separated from the paleosome by rather continuous mm-thick melanosomes. Occasionally leucosomes reach up to tens of $\mathrm{cm}$ in thickness and forms concordant tabular leucocratic bodies (Fig. 2f). As in the mylonitic gneisses, there are late Grt-absent and Crd-bearing thin dikes that seem to develop under ductile-to-fragile conditions (Fig. 2f). Porphyroblastic gneisses are likely equivalent to rocks rocks belonging to the upper part of the Grt-KyKfs zone of Torres-Roldán (1981) or the migmatites of Platt et al. (2003).

We have conducted a systematic sampling of the gneissic sequence of Jubrique and collected a total of 40 samples. Seven samples of mylonitic (JU-6, JU-7, JU-8, JU-10) and porphyroblastic (JU-16, JU-21, JU-25) gneisses were chosen to study in detail the microstructures and phase assemblages of the MI (JU-6, JU-7, JU-16), bulk rock compositions (JU-7, JU-21) and mineral major element compositions (JU-6, JU-7, JU10, JU-21, JU-25). In addition, we have also conducted a thermodynamic modeling of the mylonitic gneiss $\mathrm{JU}-7$, in order to shed light on the conditions of melt generation and entrapment. The location of these samples is shown in Figs. 1 and 3.

\subsection{Petrography and mineral chemistry of mylonitic gneisses}

Mylonitic gneisses are fine-grained rocks made of abundant to frequent Grt, Qz, Pl, Kfs, Ky, Sil and Crd, scarce to rare Bt, and accessory Spl, Gr, Ap, Rt, Ilm, Zrn, Mnz and rare Ep. These rocks show a mylonitic microstructure, with a fine-grained $(\approx 20-200$ $\mu \mathrm{m})$ matrix formed mostly by $\mathrm{Qz}+\mathrm{Pl}+\mathrm{Kfs}+\mathrm{Als} \pm \mathrm{Crd}$, and porphyroclasts of Grt and, less frequently, Ky and Kfs (Figs. 3, 4). In addition to the banding observed at the outcrop scale, the main foliation $\left(\mathrm{S}_{\mathrm{p}}\right)$ is defined by oriented ribbons of Qz, elongate Grt and Ky porphyroclasts, prisms of Ky and prisms/needles of Sil. The intensity of deformation varies within the sequence, and some dm-to-m domains may appear highly deformed, to the point that leucocratic and melanocratic bands become hardly distinguishable (Fig. 3); it is in these domains where Sil develops the largest (hundreds of $\mu \mathrm{m}$ ) crystals (Fig. 4a). In spite of the strong deformation, mineral lineations are apparently absent in the field and at the scale of hand specimen or thin section.

Garnet forms conspicuous rounded or elongated porphyroclasts ranging in size from

$230 \leq 1 \mathrm{~mm}$ up to $2 \mathrm{~cm}$, and are present within both leucocratic and melanocratic bands (Fig. 
Ilm, Zrn, Mnz, Gr and Spl (Figs. 3, 4b-e, 4g). Melt inclusions have also be observed within Qz included in Grt (Fig. 4h). Some FI, of possible primary origin, are spatially associated with MI in clusters within Grt (Fig. 4e). Muscovite has never been observed. Considering large ( $\geq 4-5 \mathrm{~mm}$ ) Grt porphyroclasts, MI, Ky and Rt are found both at cores and rims (Figs. 4b-c), whereas Sil and Ilm are only found at the rims (Fig. 4c, 4g). Mineral inclusions at the core are not oriented, whereas inclusions at rims (e.g. needles of Sil) may be oriented subparallel to $S_{p}$ (Fig. $4 \mathrm{~g}$ ). Rims of Grt are variably replaced by undeformed coronas of Crd, Qz, Bt, Ilm, Kfs, Spl and rare Pl (Fig. 4g) (see also Platt et al., 2003). Garnets are rich in Alm and $\operatorname{Prp}\left(\approx \mathrm{Alm}_{66}, \approx \operatorname{Prp}_{28}\right)$, have low to very low concentrations of Grs and Sps $\left(\approx \mathrm{Grs}_{4}, \approx \mathrm{Sps}_{2}\right)$ (Table 1, Fig. 5a), and show up to three compositional domains depending on crystal size. Crystals $\leq 3 \mathrm{~mm}$ show a central plateau in all components and increases in Grs and decreases in Prp and $\mathrm{X}_{\mathrm{Mg}}$ at some hundreds of $\mu \mathrm{m}$ from, and towards the rim. The component spessartine is flat except at a few tens of $\mu \mathrm{m}$ from the rim where it increases. In addition to these compositional zones, larger crystals ( $\geq 5 \mathrm{~mm}$ ) show a central domain with higher concentration of Grs with respect to the plateau (Fig. 5a).

Kyanite occurs both in Grt and in the matrix (Figs. 4b-d, 4g, 4i-j). Matrix Ky forms elongated porphyroclasts and small prisms, always parallel to $S_{p}$ and metastable, partially replaced by either a $\mathrm{Spl}+\mathrm{Pl} \pm \mathrm{Kfs} \pm \mathrm{Crd}$ corona (Fig. $4 \mathrm{j}$ ) or a fringe of Sil. Frequently, former Ky appears also as polycrystalline aggregates with undulose extinction, apparently pseudomorphosed by Sil (Fig. 4f). Kyanite in Grt may also be rimmed by Spl coronas (Fig. 4c-d); however, Ky included at the cores of large Grt appear stable (Fig. 4b). In addition to needles included at the rims of Grt or replacing rims of Ky, Sil appears as small oriented prisms in the matrix (including leucocratic bands), and is particularly abundant in highly deformed rocks (Figs. 4a, 4g, 4i-k). Biotite occurs mostly in coronas $\left(\mathrm{Mg} \# \approx 0.47\right.$; $\mathrm{Mg} \#=\mathrm{mol}$. $\left.\left[\mathrm{MgO} /\left(\mathrm{MgO}+\mathrm{FeO}_{\mathrm{t}}\right)\right]\right)$ around Grt (Fig. 4g), but also as inclusions within Grt $(\mathrm{Mg \#} \approx 0.69)$ (Figs. 4c, 4e) and, more rarely, in the matrix. Biotite included in Grt show the lowest Ti concentrations. Biotites of leucocratic and melanocratic bands are similar in composition $(\mathrm{Mg \#} \approx 0.51)$. Cordierite $(\mathrm{Mg \#} \approx 0.61)$ appears mostly in coronas partially replacing Grt, where it forms symplectic intergrowths with Qz; it may also appear in the fine-grained matrix of the rock. Plagioclase included in Grt $\left(\approx \mathrm{An}_{50}\right)$ is richer in An with respect to $\mathrm{Pl}$ in leucocratic and melanocratic bands, which shows similar compositions $\left(\approx \mathrm{An}_{40}\right)$. Plagioclase in leucocratic bands is either homogeneous or slightly zoned (inverse or 
direct), whereas Pl in melanocratic bands show a slight inverse zoning. Plagioclase in coronas replacing matrix Ky shows intermediate compositions $\left(\approx \mathrm{An}_{45}\right)$. K-feldspar shows a rather constant composition in all microstructural locations. Quartz appears frequently in the matrix as ribbons wrapping the porphyroclasts. Spinels are solid solutions between Spl, Hc and Ghn. Spinels included in Grt are closer to Spl and richer in $\mathrm{Zn}(\mathrm{Mg} \# \approx 0.41 ; \mathrm{ZnO} \approx 6 \mathrm{wt} \%)$, whereas spinel in coronas around $\mathrm{Grt}$ is closer to $\mathrm{Hc}$ and has low concentrations of $\mathrm{Zn}(\mathrm{Mg} \# \approx 0.19 ; \mathrm{ZnO} \approx 0.5 \mathrm{wt} \%)$.

Leucocratic bands are granitic and composed of Qz, Kfs, Pl (commonly Kfs $>\mathrm{Pl}$; Kfs may appear with rod, string or patch perthites) and accessory Ky, Sil, Grt, Rt, Ilm and Gr (Fig. 4i). They are deformed but show larger grain size compared with the rest of the rock (Figs. 3, 4i); microstructures indicating the former presence of melt such as cuspate mineral terminations, melt films and subhedral microstructures (Fig. 41; e.g. Sawyer, 2001; Vernon, 2011) are rare or absent, probably erased by deformation and high temperature annealing. Mesocratic-melanocratic bands are rich in Grt, Als and Pl.

280 Leucocratic concordant bodies are similar to leucocratic bands: they show a mylonitic microstructure and have a granitic mineral composition $(\mathrm{Qz}+\mathrm{Pl}+$ perthitic $\mathrm{Kfs})$, with frequent Grt and accessory Ky, Sil, Bt, Rt, Ilm and Spl (Fig. 4k). Garnets have abundant MI and show many microstructural features similar to Grt of the host rock, suggesting that they are entrained crystals from the residue. The late leucocratic dikes crosscutting $\mathrm{S}_{\mathrm{p}}$ are tonalitic medium-grained rocks made of $\mathrm{Qz}, \mathrm{Pl}, \mathrm{Bt}$ and Crd. They are almost undeformed and show a typically igneous subhedral microstructure. Hence they are different in composition and microstructure with respect to the leucogranitic bands/bodies parallel to $S_{p}$.

Pre-kinematic minerals (with respect to $\mathrm{S}_{\mathrm{p}}$ ) include the cores of large Grt porphyroclasts, inclusions of $\mathrm{Ky}, \mathrm{Bt}, \mathrm{Rt}$ and $\mathrm{Pl}$ in these cores (Fig. 4b), and porphyroclasts of Ky and Kfs. Syn-kinematic phases are oriented Sil within the rims of

292 large Grt, in small Grt (Fig. 4g) or in the matrix (Fig. 4a), rims of large Grt and small

293 Grt, and oriented Ilm and Bt in the matrix (Figs. 4g, 4i-j). Post-kinematic minerals 294 include Crd, Bt, Ilm, Kfs, Spl and Pl replacing rims of Grt and Ky (Figs. 4g, 4j) (see 295 also Loomis, 1972; Torres-Roldán, 1981; Balanyá et al., 1997; Argles t al., 1999; Platt 296 et al., 2003). 
Porphyroblastic gneisses are fine-to-medium grained rocks characterized by a compositional layering at the mm-cm scale (leucosome, paleosome and melanosome, see Fig. 2e), parallel to a schistosity $\left(\mathrm{S}_{\mathrm{p}}\right)$ defined by Bt, Als and Gr. Compared to mylonitic ones, porphyroblastic gneisses show lower modal proportions of Grt and Als, and higher amounts of Bt (Figs. 3 and 4). They also display a decrease in Grt and increase in Bt modal proportions towards upper structural levels. This, together with the similarity in mineralogy and many microstructures in both types of gneisses (particularly at their contact, see below), indicates a petrologic continuity throughout the entire sequence. Porphyroblastic gneisses are constituted by a fine-to-medium-grained matrix $(\approx 0.5-2 \mathrm{~mm})$ made of $\mathrm{Qz}+\mathrm{Pl}+\mathrm{Kfs}+\mathrm{Als}+\mathrm{Bt}+\mathrm{Grt} \pm \mathrm{Crd}$, that enclose Grt and $\mathrm{Kfs}$ porphyroblasts. Quartz shows undulose extinction and/or development of subgrains, and Qz and feldspars develop sutured boundaries.

Garnet porphyroblasts reach in size up to $1.5 \mathrm{~cm}$, and are in general smaller than in mylonitic gneisses. They also show replacement coronas of $\mathrm{Crd}+\mathrm{Qtz}+\mathrm{Bt}+\mathrm{Spl}$, and contain inclusions of melt (Fig. 4m), Qz, Ky, Sil, Pl, Bt, as well as Rt, Py, Gr, Zrn, Mnz, Ap and Ilm. Some FI seem primary as they appear regularly distributed throughout the entire Grt and spatially associated with MI (Fig. 4m); these may be filled with carbonates such as calcite and siderite. Garnets are rich in Alm and $\operatorname{Prp}\left(\approx \mathrm{Alm}_{66}, \approx \operatorname{Prp}_{22}\right)$ and show higher Grs and $\mathrm{Sps}\left(\approx \mathrm{Grs}_{8}, \approx \mathrm{Sps}_{4}\right)$ with respect to Grt in mylonitic gneisses.

317 Crystals $\geq 5 \mathrm{~mm}$ show a central compositional plateau and, in contrast to mylonitic gneisses, a monotonic decrease in Sps and an irregular increase in $\mathrm{Mg} \#$ towards the rims (Table 2, Fig. 5b); Grs also increases irregularly towards the rim. Crystals $\leq 2 \mathrm{~mm}$ lack the central plateau and show zoning patterns similar to rims of the large Grt.

Aluminosilicates are less abundant than in mylonitic gneisses, though their proportions vary throughout the sequence of porphyroblastic gneisses. Kyanite and Sil show similar microstructures to those in mylonitic gneisses. Besides included in Grt, Ky occurs in the matrix parallel to $S_{p}$ and frequently rimmed by symplectic coronas of $\mathrm{Spl} \pm \mathrm{Pl} \pm \mathrm{Crd}$ or by Sil (Fig. 4n). Sillimanite also appears as oriented inclusions at the rims of large Grt or throughout small Grt (Fig. 4n). Biotite occurs mostly as oriented crystals or crystal aggregates in the paleosome and melanosome, but also included

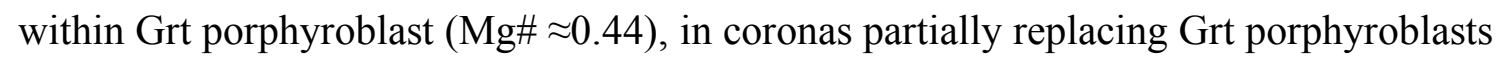
$(\mathrm{Mg} \# \approx 0.51)$, replacing small Grt in the matrix, and as individual crystals within leucosomes. Biotites in paleosome, leucosomes and replacing small Grt show similar compositions $(\mathrm{Mg} \# \approx 0.56)$; Bt replacing Grt show the highest Ti concentrations, 
332 whereas Ti contents in Bt included in Grt is higher than those in matrix Bt. Plagioclase 333 of paleosome and leucosome are similar in composition $\left(\approx \mathrm{An}_{44}\right)$, and either 334 homogeneous or show slight inverse zoning ( $\approx \mathrm{An}_{38-44}$ at cores, $\mathrm{An}_{43-48}$ at rims). 335 Plagioclase replacing small crystals of matrix Grt is richer in $\mathrm{Ca}\left(\approx \mathrm{An}_{58}\right)$. K-feldspar 336 show similar composition $\left(\approx \mathrm{Ab}_{13} \mathrm{Or}_{86}\right)$ in all microstructural locations: as inclusions in 337 Grt, in the paleosome, in leucosomes and as exsolutions within Pl of leucosomes.

338 Most of the observed leucosomes are granitic, composed of Qz, P1, Kfs and accessory Ky, Sil, Grt, Rt and Ilm; Pl commonly shows patch to braid antiperthites (Fig. 4o). More rarely, leucocratic bands are tonalitic and composed of Qz, Pl, abundant subhedral to anhedral Crd and accessory Bt and Ilm (Fig. 4p). Anhedral Crd crystals include abundant aggregates of Sil needles and, more rarely, relicts of Grt. All leucosomes commonly show igneous microstructures such as euhedral to subhedral feldspars and Crd against a Qz \pm feldspar matrix, and cuspate mineral terminations, providing this domain with a subhedral microstructure (Fig. 4o-p); this indicates that they represent former melt-rich domains (Vernon, 2011). The strong orientation of leucosomes parallel to $S_{p}$ (Figs. 2e-g), together with the presence of igneous microstructures (Figs. 4o-p), indicate pre-to-syn-kinematic melting with respect to $S_{p}$. The paleosome is rich in Grt, Bt, Als and $\mathrm{Pl}$, and show porphyroblastic (Grt, Kfs) and anhedral to xenoblastic microstructures. Porphyroblastic gneisses may appear strongly deformed, particularly towards the contact with mylonitic gneisses, with a reduction in the matrix grain size $(\approx 50-200 \mu \mathrm{m})$ and development of Qz ribbons. Late Crd-bearing thin dikes perpendicular to foliation (Fig. 2f) are medium-to-coarse grained tonalitic rocks made of Qtz, Pl, Crd and Bt; they are similar in mineralogy and microstructures to the Crd leucosomes described above (Fig. 4p).

\section{Microstructures of melt inclusions}

Former MI have been observed within Grt present throughout the entire sequence of gneisses. Rarely, they also appear within Qz crystals included in Grt (Fig. 4h). Most of them correspond to nanogranites (i.e. totally crystallized polycrystalline inclusions), whereas only a few of them are partially crystallized and include some glass, or appear as totally glassy (Figs. 4, 6, 7). The abundance of MI varies between samples, even

362 from the same outcrop. In gneisses with abundant MI ( $\approx 10-20 \mathrm{MI}$ per $\mathrm{mm}^{2}$ of Grt), they appear scattered throughout the entire host crystals; occasionally MI form clusters, 
and apparently with a random distribution within the host. In general, MI are more abundant and larger in mylonitic gneisses. Melt inclusions are isometric, often show negative crystal shapes, range in size from $\approx 5$ to $200 \mu \mathrm{m}$, and show a mean size of $\approx 30$ $40 \mu \mathrm{m}$. There is no pattern in the distribution of MI regarding their size, and small and large MI are observed next to each other. MI in the cores of large Grt occur in the vicinity of single inclusions of Ky and Rt, whereas MI at the rims of large Grt, or within small Grt, are often associated with inclusions of Ky, Sil, Rt and/or Ilm.

Nanogranites and partially crystallized MI from mylonitic and porphyroblastic gneisses are composed of daughter crystals of Qz, Kfs, Pl (albite to bytownite), ternary feldspar, Phl, Bt, Ms, rare calcite, and trapped crystals (see discussion) of Ky ( ${ }_{\mathrm{Spl}} \mathrm{Sp}$, Gr, Phl, Zrn, Mnz, Rt, Ilm and Ap (Figs. 6 and 7). Crystals of Ky are present within most of the MI, and appear to be the main accidental mineral that favored the entrapment of the inclusions during Grt growth (Figs. 6a-e, 6g-h, 6k-1, 7a-b, 7e-, 7j). These Ky crystals are mostly anhedral and, in inclusions at the rims of large Grt, commonly appear partially replaced by a low-Zn, hercynitic Spl. Occasionally, in MI located at the core-rim region of large Grt, accidental Ky appear rimmed by Spl rich in $\mathrm{Zn}$ ( $\mathrm{Zn} \approx \mathrm{Fe}$ from EDS spectrum, Figs. 6c, 7b). Other solid inclusions include Gr, Zrn and Mnz (e.g. Figs. 6a-b, 6g, 61). Ilmenite occurs only in MI located at the rim of large Grt (Figs. 6j, 7b, 71), whereas Rt, Zrn and Mnz have been found throughout the entire host (Figs. 6a-b, 6d, 6g, 7d, 7f-g, 7k-1). Glassy MI may show some minor daughter minerals nucleated on the MI walls, and/or a shrinkage bubble (Fig. 7f). The glass present in partially crystallized MI (Figs. 6b-c, 6f, 7d, 7i) and glassy MI show typical granitic EDS spectra.

Offshoots around MI have been observed in a few cases; they are filled with daughter minerals, do not necessarily show a radial distribution and, compared with the diameter of the MI, they have similar to smaller lengths (Figs. 6a, 6j-k, 7c-d, 7i). Conversely, MI are commonly affected by late fractures crosscutting the entire Grt that may produce the retrogression and partial replacement of the primary mineral assemblage of nanogranites to a cryptocrystalline and low temperature assemblage that includes Chl (Fig. 61, 7c, 7h, 71). Among the daughter minerals of MI, Bt and Ms form euhedral to subhedral crystals, are frequently intergrown, and appear to be among the first minerals that crystallize from the melt (Fig. 6g, 6j, 6k, 7c, 7i, 7k). Although some Bt crystals appear to nucleate and grow from irregular Grt surfaces (Fig. 6k), crystallization of most MI started after development of negative crystal shapes (e.g. 
399 Figs. 6e, 7d), as found by Ferrero et al. (2012). In the MI, Qz and feldspars are 400 subhedral to anhedral and are commonly intergrown (e.g. Figs. 6e, 61, 7e, 7k). Some small cavities (e.g. Figs. 6f-g) can be interpreted as micro- to nano-porosity, and preliminary results of $\mathrm{H}$ analysis of remelted nanogranites (Bartoli et al., pers. com.) suggest that they were filled with the fluid dissolved in the former hydrous melt and exsolved upon crystallization (see also Fig. 4 in Bartoli et al., 2013a). One of the studied nanogranites contains calcite in an apparently primary context (i.e. either as a daughter or a trapped crystal; Fig. 6j). However, such rare, non-systematic occurrence prevents from allowing meaningful speculations. The microscopic observations show that MI in Grt of both types of gneisses have mostly similar characteristics regarding shape, size, degree of crystallization, mineralogy and distribution in the host, MI in porphyroblastic gneisses being slightly smaller (mean size of $\approx 30 \mu \mathrm{m}$ ) and less abundant.

\section{Phase equilibria modeling and conventional thermobarometry}

All gneiss samples contain microstructures corresponding to several metamorphic stages. Furthermore, these gneisses show clear microstructures indicative of anatexis, and melt may have escaped from these deformed rocks during its metamorphic evolution (see above). Hence, the bulk rock composition of a given gneiss sample might not correspond to that of the protolith, which would influence the phase equilibria relationships and chemical compositions of minerals in the early stages of the metamorphic evolution. Inferring precise $P-T$ conditions for such complex samples requires the use of particular equilibration volumes for each metamorphic stage. Only based on such a careful work we would be able to compare calculated compositional isopleths with observed mineral compositions and estimate precise $P-T$ conditions. Such a detailed analysis is beyond the scope of this work. Here we have used the mylonitic gneiss sample JU-7 only to illustrate generalized $P-T$ conditions recorded by these rocks, based on the comparison of microstructural observations with results from phase equilibria modeling. In order to make the modeled $P-T$ conditions robust, we accompanied the phase equilibria modeling with results from conventional thermobarometry on mylonitic gneisses JU-6 and JU-7.

The model chemical system $\mathrm{Na}_{2} \mathrm{O}-\mathrm{CaO}-\mathrm{K}_{2} \mathrm{O}-\mathrm{FeO}-\mathrm{MgO}-\mathrm{Al}_{2} \mathrm{O}_{3}-\mathrm{SiO}_{2}-\mathrm{H}_{2} \mathrm{O}-\mathrm{TiO}_{2}$ 430 (NCKFMASHT) was used with the bulk rock composition obtained from XRF analysis. 431 The bulk rock composition (in mol \%) used for calculation is indicated in the upper left 
inset of the calculated $P-T$ phase diagram pseudosection (Fig. 8). The amount of $\mathrm{H}_{2} \mathrm{O}$ component involved in the calculation for the bulk rock composition was assumed as the loss of ignition of the XRF analysis. Graphite was neglected in the calculation due to its minor effect on the phase relationships under the P-T conditions of interest. All calculations were done by the Gibbs energy minimization (Connolly, 2009) with the thermodynamic database of Holland \& Powell (1998, as revised in 2003). We used the solution model of melt from White et al. (2007), garnet from Holland and Powell (2001), biotite from Tajčmanová et al. (2009), white mica from Coggon and Holland (2002) and ternary feldspar from Fuhrman and Lindsley (1988). An ideal model was used to account for the solution of cordierite.

Phase equilibria modeling provides peak $P-T$ conditions of $\approx 850^{\circ} \mathrm{C}$ and $\approx 12-14 \mathrm{kbar}$ (Grt-Bt-Fsp-Ky-Rt-Qz-Liq stability field; Fig. 8), recorded in the cores of large Grt porphyroclasts and its inclusions of $\mathrm{Ky}, \mathrm{Pl}, \mathrm{Bt}$, nanogranite and $\mathrm{Rt}$. The post-peak $P-T$ conditions, recorded in the rims of large Grt and its Sil and Bt inclusions, in the Crd coronas around Grt and in the matrix, are characterized by approximately similar $T$ but much lower $P$, below the Rt-out reaction and in the cordierite stability field, at around $\approx 5-6$ kbar (Fig. 8). Both of these $P-T$ conditions are at a higher temperature than the Ms fluid-absent melting reaction, and at slightly lower temperatures than the Bt fluid-absent melting reaction.

The GASP barometer (calibrations of Koziol and Newton, 1988; Koziol, 1989), and the Grt-Bt (calibrations of Thompson, 1976; Ferry and Spear, 1978; Hodges and Spear, 1982) and Grt-Crd thermometers (calibrations of Thompson, 1976; Holdaway and Lee, 1977; Bhattacharya et al., 1988) have been used for thermobaromentric calculations. Peak $T$ of $740-840{ }^{\circ} \mathrm{C}$ (at $10-15 \mathrm{kbar}$ ) were calculated using cores of large (5-10 $\mathrm{mm}$ ) Grt and inclusions of Bt in contact with the analyzed Grt cores. Peak $P$, calculated from cores of large Grt and inclusions of Pl in the cores, show a large variation between 8 and 12 kbar (at $750-850{ }^{\circ} \mathrm{C}$ ). Post-peak $T$ of $740-870{ }^{\circ} \mathrm{C}$ or $650-770{ }^{\circ} \mathrm{C}$ (at $4-6 \mathrm{kbar}$; Crd stability field in Fig. 8) were obtained using Grt rims and inclusions of Bt in the rims, or Grt rims and Crd coronas, respectively.

\section{Discussion}

\subsection{Primary nature and significance of the MI: comparison with previous studies}

The study of MI in crustal anatectic rocks is a rather new subject and approach to the 
documented and studied in detail in partially melted metasedimentary enclaves in El

466 Hoyazo dacite, where trapped melt solidified to glass due to rapid cooling upon ascent and extrusion of host magma (Cesare et al., 1997, 2003; Cesare and Maineri, 1999; Cesare, 2008). The glassy nature and large size of these inclusions made possible its direct analysis by EMP and LA-ICP-MS. These MI represent primary anatectic melts generated during partial melting of the enclaves at depth, because: (i) they are trapped within minerals crystallized during anatexis at pressures of $\approx 5-7 \mathrm{kbar}$; (ii) they are primary inclusions based on their distribution in the host (following criteria from Roedder (1984); (iii) they have leucogranitic compositions similar to glasses generated in experimental studies of crustal anatexis, and close to the haplogranitic eutectics (Cesare et al., 1997, 2003, 2007; Acosta-Vigil et al., 2007, 2010).

Melt inclusions were also described in crustal crystalline rocks, such as UHP gneisses and eclogites associated with subduction of continental crust (Hwang et al., 2001; Stöckhert et al., 2001, 2009; Ferrando et al., 2005; Korsakov and Hermann, 2006; Lang and Gilotti, 2007; Zeng et al., 2009; Gao et al., 2012, 2013; Liu et al., 2013), and LP-to-MP anatectic terranes associated with crustal thickening (Cesare et al., 2009, 2011; Bartoli, 2012; Ferrero et al., 2012; Bartoli et al., 2013a; Darling, 2013). In the case of UHP rocks, inclusions have been named as melt inclusions, multiphase inclusions, or polyphase inclusions, and have been interpreted as former melts or dense supercritial fluids. Several of these studies establish the primary nature of these inclusions based on either their random distribution (e.g. in Grt) or their preferred distribution along crystallographic directions (e.g. in Ky). Melt inclusions of LP-to-MP anatectic rocks contain either a polycrystalline granitic aggregate with typical igneous microstructures, or a polycrystalline granitic aggregate plus silicate glass, or only silicate glass, and hence have been named nanogranites, partially crystallized MI, and glassy MI, respectively (Ferrero et al., 2012). The primary nature of these inclusions was also established on the basis of their spatial distribution, as they show as rounded clusters of inclusions either in the center or randomly distributed throughout the host.

493 The major elements concentrations of these MI have been precisely measured in some 494 cases, either by the direct analysis of the glassy MI, or after the development of an appropriate experimental technique to remelt and homogenize nanogranites and partially crystallized MI (Bartoli et al., 2013b). In all cases these inclusions are leucogranitic in composition (Cesare et al., 2009, 2011; Bartoli, 2012; Ferrero et al., 2012; Bartoli et al., 2013a). 
As in previous studies, we interpret MI in the gneisses of Jubrique as primary and representing primary melts generated during the anatexis of the host rock. This is based on their mostly random spatial distribution throughout the entire crystals (i.e. from core to rim) of a typical peritectic mineral such as Grt, as well as on the presence of a granitic mineral assemblage and/or glass with a typical granitic EDS spectrum (Figs. 6 and 7). Melt inclusions in these rocks may appear completely crystallized, partially crystallized, or constituted by glass without any crystalline phase. All these type of inclusions may be present in the same Grt crystal. The presence of glass in inclusions from deep crystalline rocks is a rather unexpected though apparently common feature, that has been attributed to, first, a pore size effect (crystallization is inhibited in the smaller inclusions) and, second, to factors that may inhibit nucleation such as the absence of preexisting nuclei or irregularities on the MI walls (Cesare et al., 2011; Ferrero et al., 2012). This study supports the hypothesis of the pore size effect, as glass has been found in relatively small $(\leq 20 \mu \mathrm{m})$ MI. We interpret that Qz, Fsp, Kfs, Pl, Bt and Ms represent daughter minerals crystallized from the former melt, because: (i) they constitute either the major or common minor minerals that crystallize from granite melts; (ii) Qz and feldspars show intergrowth microstructures typical of simultaneous crystallization from a melt (Figs. 6h, 61); (iii) they nucleate on and crystallize from the planar walls, or adapt their shape to the negative crystal shape of MI; (iv) they fill the offshots present in some MI (Fig. 7i). Conversely, Ky, Gr, Spl, Zrn, Rt, Ilm, Mnz and some crystals of Bt and Qz are interpreted as accidental minerals trapped with the melt, based on: (i) their relative large size compared with the size of MI and their low solubility in granitic melts [e.g. see Acosta-Vigil et al. (2003) for the case of aluminosilicates; Figs. 6a, 7b]; (ii) the presence of indentations of these minerals within the walls of MI (Fig. 6g); (iii) presence of inclusions of these minerals in Grt. In particular, Ky is present within most of the studied MI, both at the cores and rims of Grt and, in addition to the above observations, Ky in MI from rims of Grt appears rimmed by low-Zn Spl as Ky crystals present in the matrix of the rock (Figs. 6k-1, 7j). The most frequent mineral that favored the trapping of MI in these gneisses was Ky, followed by Gr and more rarely Zrn, Rt, Ilm and Mnz.

Melt inclusions in this study show two remarkable features: a large size (mean of $\approx 30-40 \mu \mathrm{m}$ and maxima up to $\approx 200 \mu \mathrm{m}$ ) and the systematic presence of trapped Ky. This contrasts with MI in LP-to-MP anatectic rocks, which show a smaller size (mean and maximum diameters of $\approx 5-15 \mu \mathrm{m}$ and $\approx 50 \mu \mathrm{m}$, respectively) and were trapped in 
533 the P-T stability field of Sil. Sillimanite has not been observed as solid inclusion

534 (trapped mineral) within MI at Jubrique. Instead, the main solid inclusion, in addition to $535 \mathrm{Ky}$, are Gr, Zrn and Ilm. However, Sil has not been previously described as an 536 accidental phase within MI. Instead, the main accidental phases that helped the 537 entrapment of MI in LP-to-MP terranes are Gr and accessory minerals such as Zrn and 538 Ilm. Melt inclusions in Jubrique show a few of the characteristics found in MI of UHP 539 rocks. Reported MI in UHP terranes commonly show diameters of tens of micrometers, 540 and some of them may reach up to $100-150$ or even $200-250 \mu \mathrm{m}$. Also, some of the MI 541 in UHP rocks contain Ky. However, our very detail study did not identify minerals such 542 as diamond, phengite and paragonite within MI of Jubrique, minerals that have only 543 been described in MI from UHP rocks. Although diamond and coesite have been 544 reported in Grt from gneisses of apparently similar composition and structural location 545 in the Moroccan Rif (the southern branch of this arcuate Alpine orogen; Ruiz-Cruz and 546 Sanz de Galdeano, 2012, 2013), we have only identified graphite. Graphite occurs as 547 euhedral lamellae, and never as octahedral or rounded aggregates, which may instead 548 suggest the presence of former diamond.

\section{$549 \quad 7.2$ P-T conditions of melting and implications of nanogranites}

550 Previous studies on the $P-T$ conditions of these gneisses have mostly reported 551 isothermal or near-isothermal decompression $P-T$ paths, from $\approx 12-14$ kbar at 730-800 ${ }^{\circ} \mathrm{C}$ to $\approx 3-4$ kbar at $700-800{ }^{\circ} \mathrm{C}$ (Torres-Roldán, 1981; Balanyá et al., 1997; Argles et al., 1999; Platt et al., 2003). Among these, only Platt et al. (2003) have placed the anatectic event in the $P-T$ path: during decompression and growth of Grt rims in the field of Sil, at $\approx 6-7$ kbar and $820{ }^{\circ} \mathrm{C}$. For this, they have used the following arguments: (i) Grt rims, containing abundant Sil needles, show higher Grs contents than the cores, which they interpret to reflect partial melting in the matrix during this stage of growth; (ii) leucocratic bands, parallel to the main foliation, are assumed to represent anatectic leucosomes and to develop concomitantly to this main foliation, which is interpreted as decompressional. Partial melting has been associated with the breakdown of either white mica (Argles et al., 1999) or biotite (Platt et al., 2003).

The recent report of diamond and coesite in Grt from gneisses of the Rif (Ruiz-Cruz and Sanz de Galdeano, 2012, 2013) have led these authors to propose that the earliest metamorphic event recorded by these rocks corresponds to UHP/UHT conditions of $\mathrm{P}>$ 
event. During our detailed study, we have found no textural, mineralogical or petrologic evidence for UHP metamorphism in the investigated gneisses from the Betic Cordillera. In addition, pseudosection modeling and conventional thermobarometry place the peak $P-T$ conditions of these rocks at $\approx 12-14$ kbar and $\approx 800-850{ }^{\circ} \mathrm{C}$, with post-peak conditions characterized by similar $T$ and lower $P$ of $\approx 5-6$ kbar. The low pressure estimate is based on the first appearance of Crd in Fig. 8. The $P-T$ estimates are in accordance with petrographic observations (relationships among Grt porphyroclasts, Ky, Sil, Rt and Ilm, see below) and most of the previous thermobarometric studies.

To interpret the information provided by the nanogranites and include it in the history of the rock, it is necessary to determine the timing of its entrapment within the host Grt. Nanogranites appear throughout the entire Grt crystals, from core to rim, including the largest Grt present in the studied thin sections (up to $\approx 1 \mathrm{~cm}$ in diameter). Peak and post-peak $P-T$ conditions were obtained from the cores and rims of these largest Grt, and hence (i) nanogranites were trapped, and melt was present, during both peak and post-peak $P-T$ conditions, and (ii) most Grt in the gneisses grew in the presence of melt. These conclusions are also supported by the following microstructural observations. Nanogranites present at the cores of large Grt frequently include Ky; they may also include accidental Rt (Fig. 6). In addition, single mineral inclusions of Ky and Rt have been observed nearby nanogranites present at Grt cores. Nanogranites present at the rims of large Grt crystals frequently include also accidental $\mathrm{Ky}$, although in this case Ky appears commonly rimmed by low-Zn Spl (Fig. 6k-1); nanogranites may include Rt but also Ilm (Fig. 6j). In addition, single mineral inclusions of Ky, Sil, Rt, Rt partially transformed to Ilm, and Ilm, may appear in the vicinity of nanogranites present at the rims. This indicates that during growth of Grt rims in the field of Sil and Ilm, they trapped droples of melt present in the rock, together with relict Ky and Rt. We have not observed Sil within nanogranites, suggesting that this phase does not favor the trapping of MI as Ky does.

The above conclusions contrast with the previous hypothesis, based solely on petrographic observations and mineral compositions, that melting started during decompression and in the field of Sil (Platt et al., 2003). This constitutes an example of the potential of the study of nanogranites in anatectic rocks. A preliminary study on the remelting of these nanogranites has provided leucogranitic compositions for the melt inclusions (Barich et al., 2014). Future detailed remelting studies will shed light on the precise compositions of the primary anatectic melts and the fluid regime during partial 
melting at Jubrique. In this regard, the coexistence of MI and apparently primary carbonate-bearing FI in some of the investigated Grt (Figs. 4h, 4k) suggests that during some time in the history of these rocks granitic melts and $\mathrm{CO}_{2}$-bearing fluids coexisted. This uncommon coexistence of granitic melt and $\mathrm{CO}_{2}$-bearing fluids during generation of crustal magmas has been previously reported in rapidly cooled crustal anatectic enclaves present within volcanic rocks (Cesare et al., 2007; Ferrero et al., 2011) and, more recently, in metamorphic enclaves within granodiorites (Ferrero et al., 2014).

Many of the previous studies have linked the two main $P-T$ stages of equilibration recorded by these gneisses through an isothermal or near-isothermal decompression path (e.g. Torres-Roldán, 1981; Balanyá et al., 1997; Argles et al., 1999; Platt et al., 2003). However, several Zrn and Mnz geochronological studies conducted on these polymetamorphic have associated the main mineral assemblages in the gneisses either

612 to the Variscan, or the Alpine, or to both orogenic cycles (e.g. Michard et al., 1997; 613 Montel et al., 2000; Whitehouse and Platt, 2003; Rossetti et al., 2010). In this 614 contribution we caution over the possibility that Grt cores and Grt rims, and therefore 615 their associated $P-T$ conditions and included nanogranites, formed during two separated 616 events in time (e.g. see Montel et al., 2000; Whitehouse and Platt, 2003). In relation 617 with this, the reaction(s) responsible for the production of melt will depend on the $P-T-t$ 618 evolution of these rocks, as well as on the possibility that $\mathrm{H}_{2} \mathrm{O}$-rich fluids were present 619 during anatexis. Pseudosection modeling and measured peak and post-peak conditions 620 suggest, however, that $\mathrm{Bt}$ fluid-absent melting may have been important for the 621 production of melt, as previously suggested by Argles et al. (1999) and Platt et al. 622 (2003).

\section{Acknowledgements}

624 This work was supported by grants to C.J.G from the International Lithosphere Program 625 (CC4-MEDYNA), the Spanish Ministerio de Ciencia e Innovación (CGL2010-14848 626 073), Junta de Andalucía (RNM-131 and 2009RNM4495), and from the FP7 Marie627 Curie Action IRSES MEDYNA funded under Grant Agreement PIRSES-GA-2013628 612572. A.A.V. acknowledges funding from the Instituto Andaluz de Ciencias de la 629 Tierra for a research contract. B.C. acknowledges funding from the Italian Ministry of 630 Education, University and Research (PRIN 2010TT22SC) and the University of Padua 631 (Progetto di Ateneo CPDA107188/10). A.B. acknowledges a FPI PhD Fellowship from 632 the Ministerio de Ciencia e Innovación (Ref. BES-2011-045283). This research has 
633 benefited from EU Cohesion Policy funding from the European Regional Development 634 Fund (ERDF) and the European Social Fund (ESF) in support of innovation and

635

636

637

638

639

640

641

642

643

644

645

646

647

648

649

650

651

652

653

654

655

656

657

658

659

660

661

662

663

664

research projects and infrastructures. We thank Rosario Reyes for providing quality thin section and for sample preparation, Ángel Caballero and Antonio Pedrera for drawing figure 1, and Isabel Sánchez-Almazo for assistance with the scanning electron microscope study and backscattered electron images of melt inclusions. We are grateful to Prof. Scambelluri for the editorial handling of the article, and Dr. Ferrero and Prof. Darling for their reviews that improved a previous version of the manuscript.

\section{References}

Acosta-Vigil, A., London, D., Morgan VI, G.B., Dewers, T.A., 2003. Solubility of excess alumina in hydrous granitic melts in equilibrium with peraluminous minerals at $700-800^{\circ} \mathrm{C}$ and $200 \mathrm{MPa}$, and applications of the aluminum saturation index. Contributions to Mineralogy and Petrology 146, 100-119.

Acosta-Vigil, A., Cesare, B., London, D., Morgan VI, G.B., 2007. Microstructures and composition of melt inclusions in a crustal anatectic environment, represented by metapelitic enclaves within El Hoyazo dacites, SE Spain. Chemical Geology 235, $450-465$.

Acosta-Vigil, A., Buick, I., Hermann, J., Cesare, B., Rubatto, D., London, D., Morgan VI, G.B., 2010. Mechanisms of crustal anatexis: a geochemical study of partially melted metapelitic enclaves and host dacite, SE Spain. Journal of Petrology 51, 785821.

Andrieux, J., Fontbotte, J.M., Mattauer, M., 1971. Sur un modèle explicatif de l'arc de Gibraltar. Earth and Planetary Science Letters 12, 191-198.

Argles, T.W., Platt, J.P., Waters, D.J., 1999. Attenuation and excision of a crustal section during extensional exhumation: the Carratraca Massif, Betic Cordillera, Southern Spain. Journal of the Geological Society of London 156, 149-162.

Balanyá, J.C., García-Dueñas, V., Azañón, J.M., 1997. Alternating contractional and extensional events in the Alpujarride nappes of the Alboran Domain (Betics, Gibraltar Arc). Tectonics 16, 226-238.

Barich, A., Bartoli, O., Acosta-Vigil, A., Poli, S., Cesare, B., Garrido, C.J. (2014). Remelting of nanogranites in peritectic garnet from granulites of Jubrique, Betic Cordillera, Southern Spain. Geophysical Research Abstracts 16, EGU2014-12300. 
665 Bartoli, O., 2012. When the continental crust melts: a combined study of melt 666 inclusions and classical petrology on the Ronda migmatites. Unpublished PhD Thesis, Università degli Studi di Parma, p. 128.

Bartoli, O., Cesare, B., Poli, S., Bodnar, R.J., Acosta-Vigil, A., Frezzotti, M.L., Meli, S., 2013a. Recovering the composition of melt and the fluid regime at the onset of crustal anatexis and S-type granite formation. Geology 41, 115-118.

Bartoli, O., Cesare, B., Poli, S., Acosta-Vigil, A., Esposito, R., Turina, A., Bodnar, R.J., Angel, R.J., Hunter, J., 2013b. Nanogranite inclusions in migmatitic garnet: behavior during piston cylinder re-melting experiments. Geofluids 13, 405-420.

Bartoli, O., Cesare, B., Remusat, L., Acosta-Vigil, A., Poli, S., 2014. The $\mathrm{H}_{2} \mathrm{O}$ content of granite embryos. Earth and Planetary Science Letters 395, 281-290.

Bhattacharya, A., Mazumder, A.C., Sen, S.K., 1988. Fe-Mg mixing in cordierite: constraints from natural data and implications for cordierite-garnet geothermometry in granulites. American Mineralogist 73, 338-344.

Bodnar, R.J., Student, J.J., 2006. Melt inclusions in plutonic rocks: petrography and microthermometry. In: Webster, J.D. (Ed.), Melt inclusions in plutonic rocks. Mineralogical Association of Canada, Short Course 36, 1-26.

Cesare, B., 2008. Crustal melting: working with enclaves. In: Sawyer, E.W., Brown, M. (Eds.), Working with Migmatites. Mineralogical Association of Canada, Short Course 38, 37-55.

686

Cesare, B., Maineri, C., 1999. Fluid-present anatexis of metapelites at El Joyazo (SE Spain): constraints from Raman spectroscopy of graphite. Contributions to Mineralogy and Petrology 135, 41-52.

Cesare, B., Salvioli-Mariani, E., Venturelli, G., 1997. Crustal anatexis and melt extraction during deformation in the restitic xenoliths at El Joyazo (SE Spain). Mineralogical Magazine 61, 15-27.

Cesare, B., Gómez-Pugnaire, M.T., Rubatto, D., 2003. Residence time of S-type anatectic magmas beneath the Neogene Volcanic Province of SE Spain: a zircon and monazite SHRIMP study. Contributions to Mineralogy and Petrology 146, 28-43.

Cesare, B., Maineri, C., Baron Toaldo, A., Pedron, D., Acosta-Vigil, A., 2007. Immiscibility between carbonic fluids and granitic melts during crustal anatexis: a fluid and melt inclusion study in the enclaves of the Neogene Volcanic Province of SE Spain. Chemical Geology 237, 433-449. 
Cesare, B., Ferrero, S., Salvioli-Mariani, E., Pedron, D., Cavallo, A. 2009. Nanogranite and glassy inclusions: the anatectic melt in migmatites and granulites. Geology, 37, $627-630$.

Cesare, B., Acosta-Vigil A., Ferrero, S., Bartoli O., 2011. Melt inclusions in migmatites and granulites. In: Forster, M.A., Fitz Gerald, J.D. (Eds.), The Science of Microstructure - Part II. Journal of the Virtual Explorer, Electronic Edition, ISSN $1441-8142,38$, paper 2.

Clemens, J.D., 2006. Melting of the continental crust: fluid regimes, melting reactions, and source-rock fertility. In: Brown, M., Rushmer, T. (Eds.), Evolution and differentiation of the continental crust. Cambridge University Press, Cambridge, pp. 296-330.

Coggon, R., Holland, T. J. B., 2002. Mixing properties of phengitic micas and revised garnet-phengite thermobarometers. Journal of Metamorphic Geology 20, 683-696.

Connolly, J.A.D., 2009. The geodynamic equation of state: what and how. Geochemistry Geophysics Geosystems 10, Q10014.

Darling, R.S., 2013. Zircon-bearing, crystallized melt inclusions in peritectic garnet from the western Adirondack Mountains, New York State, USA. Geofluids 13, 453459.

Dewey, J.F., Helman, M.L., Turco, E., Hutton, D.H.W., Knott, S.D., 1989. Kinematics of the western Mediterranean. In: Coward, M.P., Dietrich, D., Park, R.G. (Eds.), Alpine Tectonics. Geological Society of London, Special Publication, pp. 265-283.

Ferrando, S., Frezzotti, M.L., Dallai, L., Compagnoni, R., 2005. Multiphase solid inclusions in UHP rocks (Su-Lu, China): remnants of supercritical silicate-rich aqueous fluids released during continental subduction. Chemical Geology 223, 6881.

Ferrero, S., Bodnar, R.J., Cesare, B., Viti, C., 2011. Re-equilibration of primary fluid inclusions in peritectic garnet from metapelitic enclaves, El Hoyazo, Spain. Lithos $124,117-131$.

Ferrero, S., Bartoli, O., Cesare, B., Salvioli-Mariani, E., Acosta-Vigil, A., Cavallo, A., Groppo, C. and Battiston, S., 2012. Microstructures of melt inclusions in anatectic metasedimentary rocks. Journal of Metamorphic Geology 30, 303-322.

Ferrero, S., Braga, R., Berkesi, M., Cesare, B., Laridhi Ouazaa, N., 2014. Production of metaluminous melt during fluid-present anatexis: an example from the Maghrebian 
basement, La Galite Archipelago, central Mediterranean. Journal of Metamorphic Geology 32, 209-225.

Ferry, J.M., Spear, F.S., 1978. Experimental calibration of the partition of Fe and Mg between biotite and garnet. Contributions to Mineralogy and Petrology 66, 113-117.

Fuhrman, M.L., Lindsley, D.H., 1988. Ternary-feldspar modeling and thermometry. American Mineralogist 73, 201-215.

Gao, X.Y., Zheng, Y.F., Chen, Y.X., 2012. Dehydration melting of ultrahigh-pressure eclogite in the Dabie orogen: evidence from multiphase solid inclusions in garnet. Journal of Metamorphic Geology 30, 193-212.

Gao, X.-Y., Zheng, Y.-F., Chen, Y.-X., Hu, Z., 2013. Trace element composition of continentally subducted slab-derived melt: insight from multiphase solid inclusions in ultrahigh-pressure eclogite in the Dabie orogen. Journal of Metamorphic Geology $31,453-468$.

Garrido, C.J., Gueydan, F., Booth-Rea, G., Precigout, J., Hidas, K., Padrón-Navarta, J.A., Marchesi, C., 2011. Garnet lherzolite and garnet-spinel mylonite in the Ronda peridotite: vestiges of Oligocene backarc mantle lithospheric extension in the western Mediterranean. Geology 39, 927-930.

Gurenko, A.A., Trumbull, R.B., Thomas, R., Lindsay, J.M., 2005. A melt inclusion system from the Plat Pays Volcanic Complex, Dominica, Lesser Antilles. Journal of Petrology 12, 2495-2526.

Hodges, K.V., Spear, F.S., 1982. Geothermometry, geobarometry and the $\mathrm{Al}_{2} \mathrm{SiO}_{5}$ triple point at the Mt. Moosilauke, New Hampshire. American Mineralogist 67, 11181134.

Holdaway, M.J., Lee, S.M., 1977. Fe-Mg cordierite stability in high-grade pelitic rocks based on experimental, theoretical and natural observations. Contributions to Mineralogy and Petrology 63, 175-198.

Holland, T. J. B., Powell, R., 1998. An internally consistent thermodynamic data set for phases of petrological interest. Journal of Metamorphic Geology 16, 309-343.

Holland, T.J.B., Powell, R., 2001. Calculation of phase relations involving haplogranitic melts using an internally consistent thermodynamic data set. Journal of Petrology 42, 673-683.

Holland, T. J. B., Powell, R., 2003. Activity-composition relations for phases in petrological calculations: an asymmetric multicomponent formulation. Contributions to Mineralogy and Petrology 145, 492-501. 
Hwang, S.-L., Shen, P., Chu, H.-T., Yui, T.-F., Lin, C.-C., 2001. Genesis of microdiamonds from melt and associated multiphase inclusions in garnet of ultrahigh-pressure gneiss from Erzgebirge, Germany. Earth and Planetary Science Letters 188, 9-15.

Korsakov, A.V., Hermann, J., 2006. Silicate and carbonate melt inclusions associated with diamonds in deeply subducted carbonate rocks. Earth and Planetary Science Letters 241, 104-118.

Koziol, A.M., 1989. Recalibration of the garnet-plagioclase- $\mathrm{Al}_{2} \mathrm{SiO}_{5}$-quartz (GASP) geobarometer and applications to natural parageneses. EOS, Transactions, American Geophysical Union 70, 943.

Koziol, A.M., Newton, R.C., 1988. Redetermination of the anorthite breakdown reaction and improvement of the plagioclase-garnet- $\mathrm{Al}_{2} \mathrm{SiO}_{5}$-quartz geobarometer. American Mineralogist 73, 216-223.

Lang, H.M., Gilotti, J.A., 2007. Partial melting of metapelites at ultrahigh-pressure conditions, Greenland Caledonides. Journal of Metamorphic Geology 25, 129-147.

Lenoir, X., Garrido, C.J., Bodinier, J.L., Dautria, J.M., Gervilla, F., 2001. The recrystallization front of the Ronda peridotite: evidence for melting and thermal erosion of subcontinental lithospheric mantle beneath the Alborán basin. Journal of Petrology 42, 141-158.

Liu, Q., Hermann, J., Zhang, J., 2013. Polyphase inclusions in the Shuanghe UHP eclogites formed by subsolidus transformation and incipient melting during exhumation of deeply subducted crust. Lithos 177, 91-109.

Loomis, T.P., 1972. Contact metamorphism of pelitic rocks by the Ronda ultramafic intrusion, southern Spain. Geological Society of America Bulletin 83, 2449-2474.

Lundeen, M.T., 1978. Emplacement of the Ronda peridotite, Sierra Bermeja, Spain. Geological Society of America Bulletin 89, 172-180.

Malaspina, N., Hermann, J., Scambelluri, M., Compagnoni, R., 2006. Polyphase inclusions in garnet-orthopyroxenite (Dabie Shan, China) as monitors for matasomatism and fluid-related trace element transfer in subduction zone peridotite. Earth and Planetary Science Letters 249, 173-187.

Martín-Algarra, A., 1987. Evolución geológica alpina del contacto entre las Zonas Internas y las Zonas Externas de la Cordillera Bética. PhD Thesis, Universidad de Granada, p. 1171. 
Mazzoli, S., Martín-Algarra, A., 2011. Deformation partitioning during transpressional emplacement of a 'mantle extrusion wedge': the Ronda peridotites, western Betic Cordillera, Spain. Journal of the Geological Society of London 168, 373-382.

Michard, A., Goffé, B., Bouybaouene, M.L., Saddiqi, O., 1997. Late Hercynian-Mesozoic thinning in the Alboran domain: metamorphic data from the northern Rif, Morocco. Terra Nova 9, 171-174.

Montel, J.M., Kornprobst, J., Vielzeuf, D., 2000. Preservation of old U-Th-Pb ages in shielded monazite: example from the Beni Bousera Hercynian kinzigites (Morocco). Journal of Metamorphic Geology 18, 335-342.

Olmo, A., Pablo, J.G., Aldaya, F., Campos, J., Chacón, J., García-Dueñas, V., García-Rosell, L., Sanz de Galdeano, C., Orozco, M., Torres-Roldán, R., 1980. Mapa y memoria explicativa de la hoja 1064 (Cortes de la Frontera) del Mapa Geológico Nacional a escala 1:50.000. Instituto Geológico y Minero de España.

Obata, M., 1980. The Ronda peridotite: garnet-, spinel-, and plagioclase-lherzolite facies and the $\mathrm{P}-\mathrm{T}$ trajectories of a high-temperature mantle intrusion. Journal of Petrology 21, 533-572

Perchuk, A.L., Burchard, M., Maresch, W.V, Schertl, H.-P., 2008. Melting of hydrous and carbonate mineral inclusions in garnet host during ultrahigh pressure experiments. Lithos 103, 25-45.

Platt J.P., Argles T.W., Carter A., Kelley S.P., Whitehouse M.J., Lonergan L., 2003. Exhumation of the Ronda peridotite and its crustal envelope: constraints from thermal modelling of a P-T-time array. Journal of the Geological Society of London $160,655-676$.

Platt, J.P., Behr, W.M., Johanesen, K., Williams, J.R., 2013. The Betic-Rif arc and its orogenic hinterland: a review. Annual Review of Earth and Planetary Sciences 41, $14.1-14.45$.

Roedder, E., 1984. Fluid Inclusions. Mineralogical Society of America, Reviews in Mineralogy 12, p. 644.

Rossetti, F., Theye, T., Lucci, F., Bouybaouene, M.L., Dini, A., Gerdes, A., Phillips, D., Cozzupoli, D., 2010. Timing and modes of granite magmatism in the core of the Alborán Domain, Rif chain, northern Morocco: implications for the Alpine evolution of the western Mediterranean. Tectonics 29, doi: 10.1029/2009TC002487. 
830 Ruiz-Cruz, M.D., Sanz de Galdeano, C., 2012. Diamond and coesite in the ultrahigh-

831

832

833

834

835

836

837

838

839

840

841

842

843

844

845

846

847

848

849

850

851

852

853

854

855

856

857

858

859

860

861

862 pressure-ultrahigh-temperature granulites from Ceuta, northern Rif, northwest Africa. Mineralogical Magazine 76, 683-705.

Ruiz-Cruz, M.D., Sanz de Galdeano, C., 2013. Coesite and diamond inclusions, exsolutions microstructures and chemical patterns in ultrahigh pressure garnet from Ceuta (Northern Rif, Spain). Lithos 177, 184-206.

Sanz de Galdeano, C., Andreo, B., 1995. Structure of Sierra Blanca (Alpujárride complex, west of the Betic Cordillera). Estudios Geológicos 51, 43-55.

Sawyer, E.W., 2001. Melt segregation in the continental crust: distribution and movement of melt in anatectic rocks. Journal of Metamorhic Geology 19, 291-309.

Sawyer, E.W., 2008. Atlas of Migmatites. The Canadian Mineralogist Special Publication 9, NRC Research Press, Ottawa, Ontario, Canada.

Sawyer, E. W., Cesare, B., Brown, M. 2011. When the continental crust melts. Elements 7, 229-234.

Sorby, H.C., 1858. On the microscopical structure of crystals, indicating origin of minerals and rocks. Quarterly Journal of the Geological Society of London 14, 453500.

Stöckhert, B., Duyster, J., Trepmann, C., Massonne, H.-J., 2001. Microdiamonds daughter crystals precipitated from supercritical $\mathrm{COH}+$ silicate fluids included in garnet, Erzgebirge, Germany. Geology 29, 391-394.

Stöckhert, B., Trepmann, C.A., Massonne, H.-J., 2009. Decrepitated UHP fluid inclusions: about diverse phase assemblages and extreme decompression rates (Erzgebirge, Germany). Journal of Metamorphic Geology 27, 673-684.

Tajčmanová, L., Conolly, J.A.D., Cesare, B. 2009. A thermodynamic model for titanium and ferric iron solution in biotite. Journal of Metamorphic Geology 27, 153-165.

Thomas, R., Davidson, P., 2013. The missing link between granites and granitic pegmatites. Journal of Geosciences 58, 183-200.

Thompson, A.B., 1976. Mineral reactions in pelitic rocks: II. Calculations of some $\mathrm{P}-\mathrm{T}-\mathrm{X}(\mathrm{Fe}-\mathrm{Mg})$ phase relationships. American Journal of Science 276, 425-454.

Torres-Roldán, R.L., 1981. Plurifacial metamorphic evolution of the Sierra Bermeja peridotite aureole (southern Spain). Estudios Geologicos 37, 115-133.

Tubía, J.M., Cuevas, J., 1986. High-temperature emplacement of the Los Reales peridotite nappe (Betic Cordillera, Spain). Journal of Structural Geology 8, 473-482. 
Tubía, J.M., Cuevas, J., Esteban, J.J., 2013. Localization of deformation and kinematics shift during the hot emplacement of the Ronda peridotites (Betic Cordilleras, southern Spain). Journal of Structural Geology 50, 148-160.

Van der Wal, D., Vissers, R.L.M., 1996. Structural petrology of the Ronda peridotite, SW Spain: deformation history. Journal of Petrology 37, 23-43.

Vernon, R.H., 2011. Microstructures of melt-bearing regional metamorphic rocks. In: Van Reenen, D.D., Kramers, J.D., McCourt, S., Perchuk, L.L. (Eds.), Origin and Evolution of Precambrian High-Grade Gneiss Terranes, with Special Emphasis on the Limpopo Complex of Southern Africa. Geological Society of America Memoir 207, 1-11.

Wanless, V.D., Behn, M.D., Shaw, A.M., Plank, T., 2014. Variations in melting dynamics and mantle compositions along the Eastern Volcanic Zone of the Gakkel Ridge: insights from olivine-hosted melt inclusions. Contributions to Mineralogy and Petrology 167, 1005.

Webster, J.D., Thomas, R., Rhede, D., Förster, H.-J., Seltmann, R., 1997. Melt inclusions in quartz from an evolved peraluminous pegmatite: geochemical evidence for strong tin enrichment in fluorine-rich and phosphorus-rich residual liquids. Geochimica et Cosmochimica Acta 61, 2589-2604.

White R.W., Powell R., Holland T.J.B., 2007. Progress relating to calculation of partial melting equilibria for metapelites. Journal of Metamorphic Geology 25, 511-527.

Whitehouse, M.J., Platt, J.P., 2003. Dating high-grade metamorphism-constraints from rare-earth elements in zircon and garnet. Contributions to Mineralogy and Petrology $145,61-74$.

Whitney, D.L., Evans, B.W., 2010. Abbreviations for names of rock-forming minerals. American Mineralogist 95, 185-187.

Zeng, L.S., Liang, F.H., Asimow, P., Chen, F.Y., Chen, J., 2009. Partial melting of deeply subducted continental crust and the formation of quartzofeldspathic polyphase inclusions in the Sulu UHP eclogites. Chinese Science Bulletin 54, 25802594.

\section{Tables}

Table 1. Bulk rock composition (JU-7) and electron microprobe mineral analyses (JU6, JU-7, JU-10) of mylonitic gneisses (in wt \%). 
Table 2. Bulk rock composition (JU-21) and electron microprobe mineral analyses (JU$21, \mathrm{JU}-25$ ) of porphyroblastic gneisses (in wt \%).

\section{Figure captions}

898 Figure 1. Geologic maps of the Betic-Rif orogen (a) and the western Betic Cordillera (b) 899 (modified from Balanyá et al., 1997; including data from Martín-Algarra, 1987; Sanz 900 de Galdeano and Andreo, 1995; Mazzoli and Martín-Algarra, 2011; Tubía et al., 2013), showing the location of the Jubrique unit and studied samples (see also Fig. 3).

Figure 2. Field appearance of the mylonitic (a-d) and porphyroblastic (e-g) gneisses. (ab) Mylonitic gneisses appear commonly as dark, massive and Grt-rich rocks except for the presence of mm-to-cm leucocratic bands that alternate with $\mathrm{cm}$-to-dm mesocratic-to-melanocratic bands, defining a foliation. Based on this structure, and referred to the nomenclature of migmatites, these rocks can be classified as stromatic metatexitic migmatites, where leucocratic bands correspond to leucosomes (L), melanocratic bands to melanosome (M), and mesocratic bands to paleosome (P). Some domains are less affected by the deformation -central part of (a), appear to record a previous stage in the history of the rock, and are classified as dilatant metatexitic migmatites. These domains show a higher proportion of leucosome, which appear distributed within layers parallel to foliation, but also in veins and pods at high angle or perpendicular to the foliation ( $\mathrm{a}$; white arrows). The hammer and pen are $29 \mathrm{~cm}$ and $14 \mathrm{~cm}$ long, respectively.

(c) Thick concordant Grt-rich leucocratic body affected by a foliation marked by scarce melanocratic minerals, elongated Grt and schlierens (white arrows), parallel to that in the host rock. The coin is $25 \mathrm{~mm}$ across. (d) Thin Grt-absent and Bt-Crd-bearing leucocratic dikes crosscutting the foliation at high angle that seem to form under ductile-to-fragile conditions -see also red arrow in (a). (e) Porphyroblastic gneisses; based on the structure this rock can be classified as a stromatic metatexite. The foliation is defined by alternating mm-to-dm Grt-bearing leucosomes (L, leucocratic bands), paleosomes (P, mesocratic bands) and melanosomes (red arrows, melanocratic bands). Melanosomes around leucosomes are frequent and rather continuous. (f) Porphyroblastic gneiss showing a thick concordant Grt-bearing leucocratic body (white arrow), and a thin Grt-absent and Bt-Crd-bearing dike (red arrow) that crosscut the foliation at high angle and develop under ductile-to-fragile conditions. The hammer head is $12 \mathrm{~cm}$ across. (g). 
Porphyroblastic gneisses; based on the structure this rock can be classified as a schlieren diatexite.

Figure 3. NW-SE cross-section of the contact between Ronda peridotites and Jubrique gneisses in the studied area (yellow star in Fig. 1), based on Olmo et al. (1980), Van der Wal and Vissers (1996), Balanyá et al. (1997), and data from this work. The cross-section shows the location of the studied samples and the microstructural evolution of gneisses as a function of distance to the top of the Ronda peridotite slab. Red arrows show the location of leucosomes at the thin-section scale. White lines in peridotites and black likes in gneisses show the traces of the mylonitic foliation. The traces of the schistosity in the porphyroblastic gneisses, parallel to the mylonitic foliation, have not been represented. See text for details.

Figure 4. Petrographic photomicrographs from mylonitic (a-l) and porphyroblastic (mp) gneisses. (a) Prisms of Sil crystallized parallel to foliation in the matrix (hereafter marked by red line). (b) Core of large Grt $(\approx 6 \mathrm{~mm}$ in diameter, center of the Grt is marked by red dot), showing mineral inclusions of Rt, Ky, Qz and Pl, and abundant MI (red arrows). (c) Rim of the same large Grt from (b), showing single mineral inclusions of Rt, Ilm, Bt, and abundant MI (red arrows). Notice the large MI that includes Ky rimmed by Spl. (d) Melt inclusions in Grt of mylonitic gneisses show a large range in size. Compare the large MI shown in this figure (red arrows) with those in (b-c) and (e-f). These large MI include in all cases Ky (sometimes rimmed by $\mathrm{Spl}$ ), in addition to Qz, feldspars and Bt. (e) Garnet showing coexisting MI (red arrow) and apparently primary FI (white arrow). (f) Glassy MI with srinkage bubble in Grt of mylonitic gneiss. (g) Garnet porphyroclasts in a matrix of Qz, feldspars and aluminosilicates (Ky and Sil). The matrix foliation is defined by Qz ribbons and oriented Ky and Sil. Inclusions of Sil needles (red arrows) appear throughout the entire smaller Grt $(\approx 1 \mathrm{~mm})$ but only at the rims of the larger Grt $(\approx 3 \mathrm{~mm})$. Garnets show replacement coronas of $\mathrm{Crd}+\mathrm{Qz}+\mathrm{Bt}+\mathrm{Spl}+\mathrm{Ilm} \pm \mathrm{Pl}$. (h) MI in Qz within Grt of mylonitic gneiss. (i) Deformed leucosome formed by a fine-grained quartzofeldspathic matrix, feldspar porphyroclasts and accessory Ky (white arrow), Sil, Grt and Rt. Kyanite is rimmed by a $\mathrm{Spl}+\mathrm{Pl} \pm \mathrm{Crd} \pm \mathrm{Kfs}$ corona. Red arrow shows perthitic Kfs. The foliation in leucosomes is defined by oriented Qz ribbons, feldspar porphyroclasts, Ky and Sil. (j) Microstructures of aluminosilicates in the matrix of mylonitic gneisses. Relict Ky appears partially replaced by a corona of $\mathrm{Spl}+\mathrm{P} 1 \pm \mathrm{Crd} \pm \mathrm{Kfs}$. Sillimanite appears mostly as pseudomorphs after former $\mathrm{Ky}$, 
constituting polycrystalline aggregates or single crystals with undulose extinction; it also forms small needles replacing former Ky (see fibers around Sil pseudomorphs). Matrix Ky and Sil are always oriented parallel or subparallel to foliation. (k) Concordant Grt-rich leucocratic body in mylonitic gneisses (see Fig. 2c). This rock has a granitic mineral composition and a mylonitic microstructure, with a finegrained matrix $(\approx 50-200 \mu \mathrm{m})$ composed of $\mathrm{Qz}+\mathrm{Pl}+\mathrm{Kfs}$, that encloses abundant $\mathrm{Qz}$ ribbons and Kfs and Grt porphyroclast up to $\approx 1 \mathrm{~cm}$ in diameter. Kyanite appears rimmed and partially replaced by Spl or Sil fibers. The foliation (red line) is defined by Qz ribbons and accessory Bt, Ky, Sil, Rt and Ilm. (1) Igneous microstructures in leucosome of mylonitic gneiss, such as cuspate mineral terminations, melt films and subhedral microstructures (white arrows). (m) Large elongated garnet $(\approx 3 \times 6 \mathrm{~mm})$ of porphyroblastic gneiss showing abundant coexisting MI (red arrow) and apparently primary FI (white arrow). (n) Small elongated Grt in porphyroblastic gneiss showing abundant inclusions of Sil needles throughout the entire crystal. Sillimanite inclusions are mostly oriented parallel to the foliation in the matrix, defined by Ky prisms (red arrows), Sil pseudomorphs and Bt. (o) Granitic leucosome in porphyroblastic gneiss showing a subhedral to anhedral igneous microstructure and accessory Ky (red arrows), Sil, Grt and Bt. Notice Pl with antiperthites, and thin coronas around relict Ky. (p) Tonalitic leucosome in porphyroblastic gneiss with subheral microstructure, formed by Qz, subhedral to anhedral Pl and Crd, and Bt. These leucosomes are oriented parallel to $\mathrm{S}_{\mathrm{p}}$; in spite of this, only Qz appears slightly deformed and shows undulose extinction, whereas subhedral Crd prisms are parallel to $\mathrm{S}_{\mathrm{p}}$.

Figure 5. Major element concentration profiles (from EMP analyses) measured through the apparent center of large garnets from mylonitic gneisses (a) and porphyroblastic gneisses (b). Concentration scale for Grs and Sps is four times (a) or three times (b) that for Alm, Prp and Mg\#.

Figure 6. Backscattered electron images of selected nanogranites and partially crystallized melt inclusions in garnets of mylonitic gneisses JU-6 and JU-8, as a function of the region in the garnet (core, core-rim, and rim). See text for details.

Figure 7. Backscattered electron images of selected nanogranites, partially crystallized melt inclusions, and glassy melt inclusions in garnets of porphyroblastic gneiss JU16 , as a function of the region in the garnet (core, core-rim, and rim). See text for details. 
995 Figure. 8. $P-T$ section for the mylonitic gneiss JU-7 calculated in the system

996 NCKFMASHT. Regions 1 and 2 indicate peak and post-peak $P$ - $T$ conditions,

997 respectively, calculated based on phase equilibria modeling, conventional

998 thermobarometry and microstructural observations. Liquid-in, Ms-out, Bt-out and

999 Rt-out reactions are also shown. See text for details.

1000 


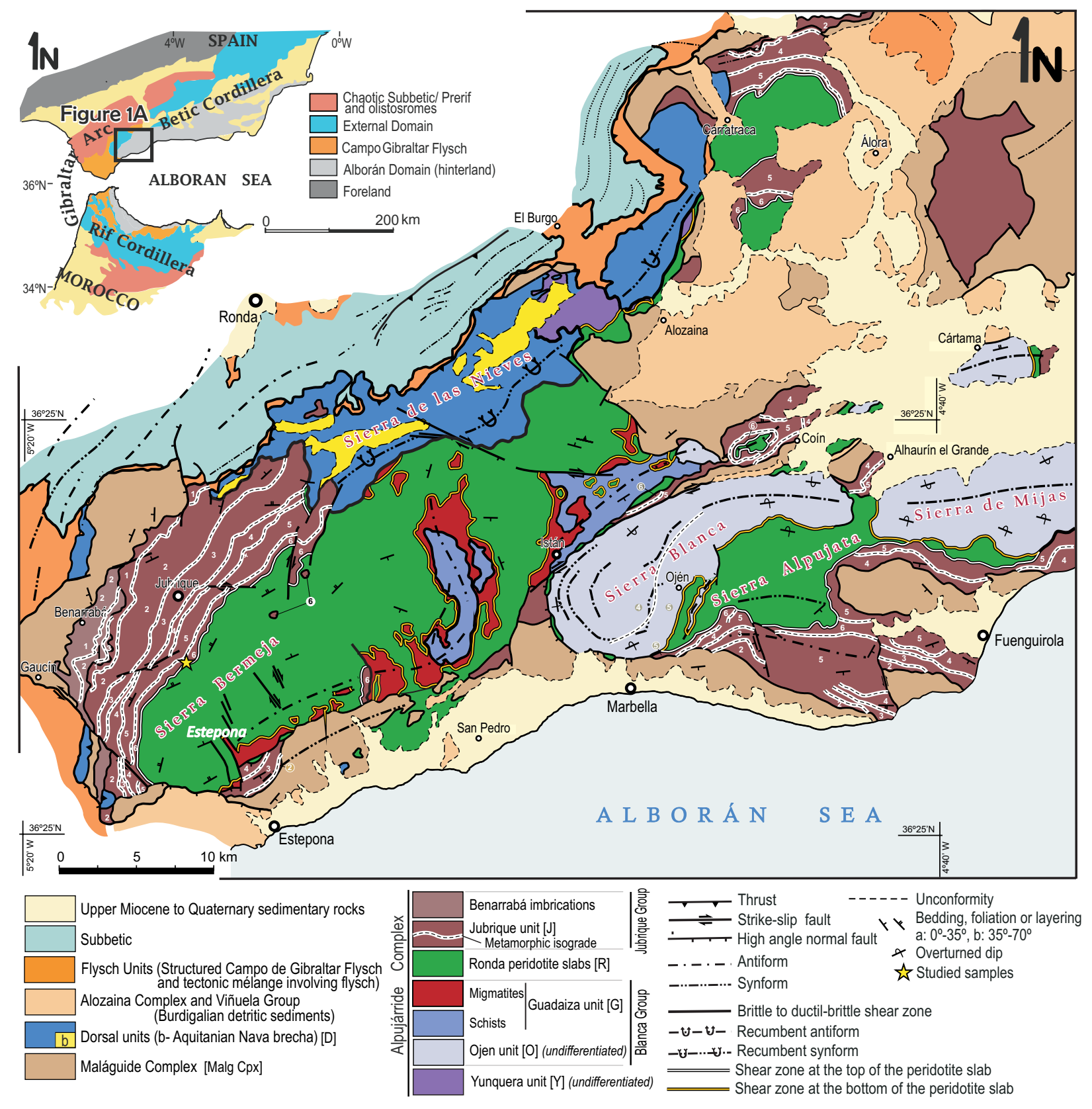




\section{$\mathrm{a}$}

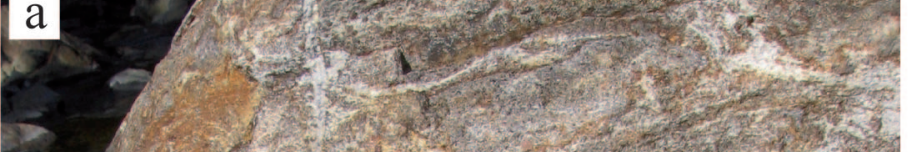

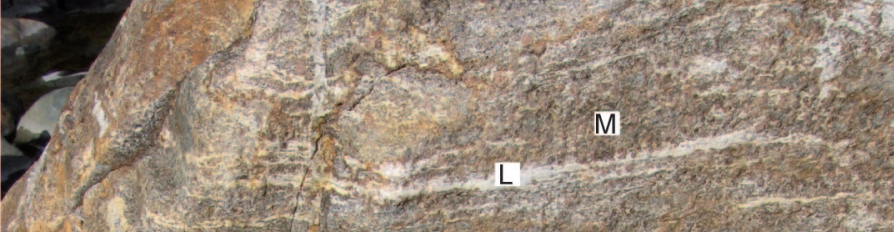

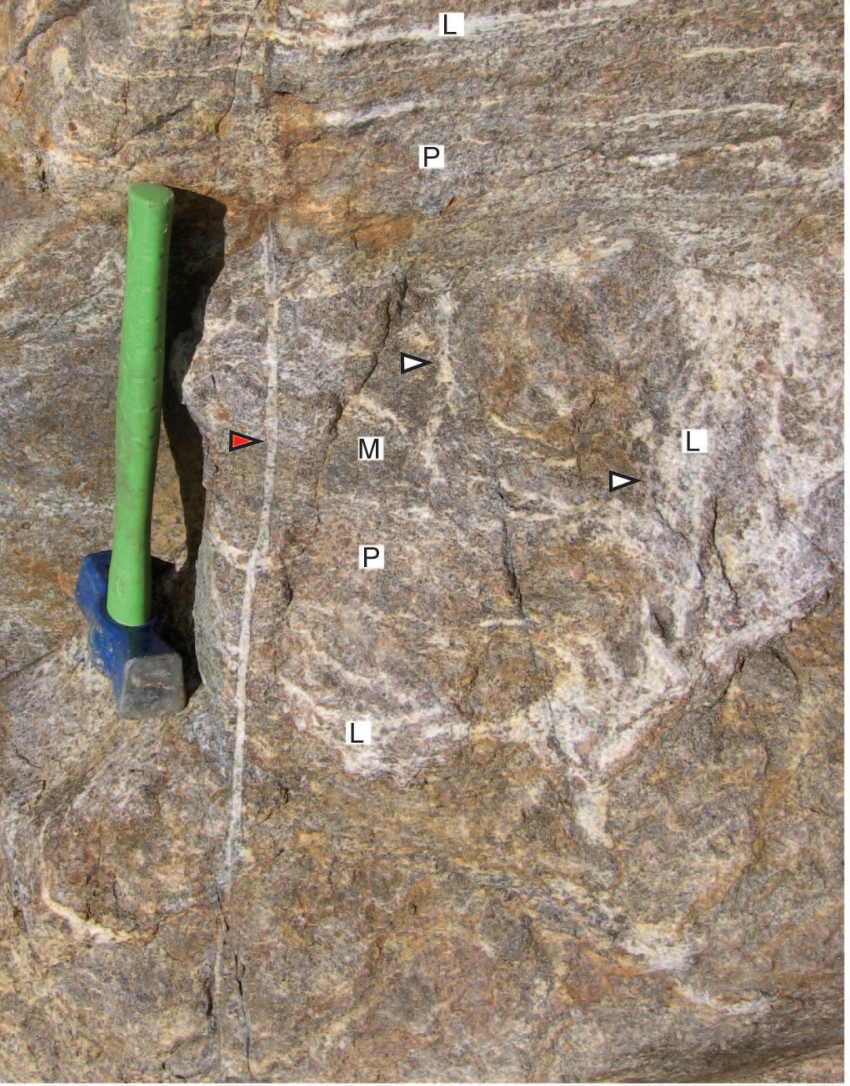

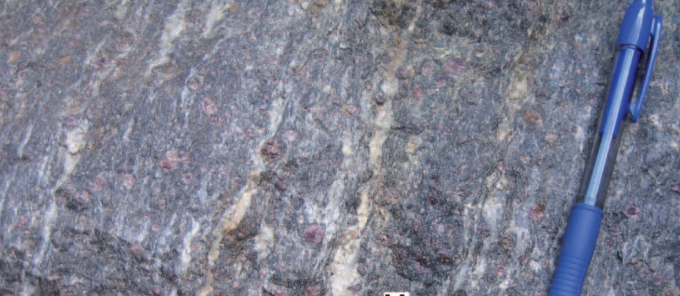

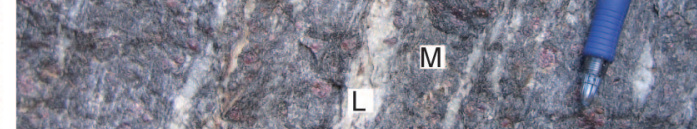

(2)

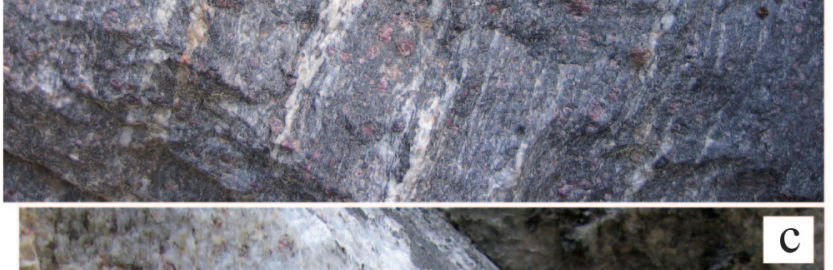

d

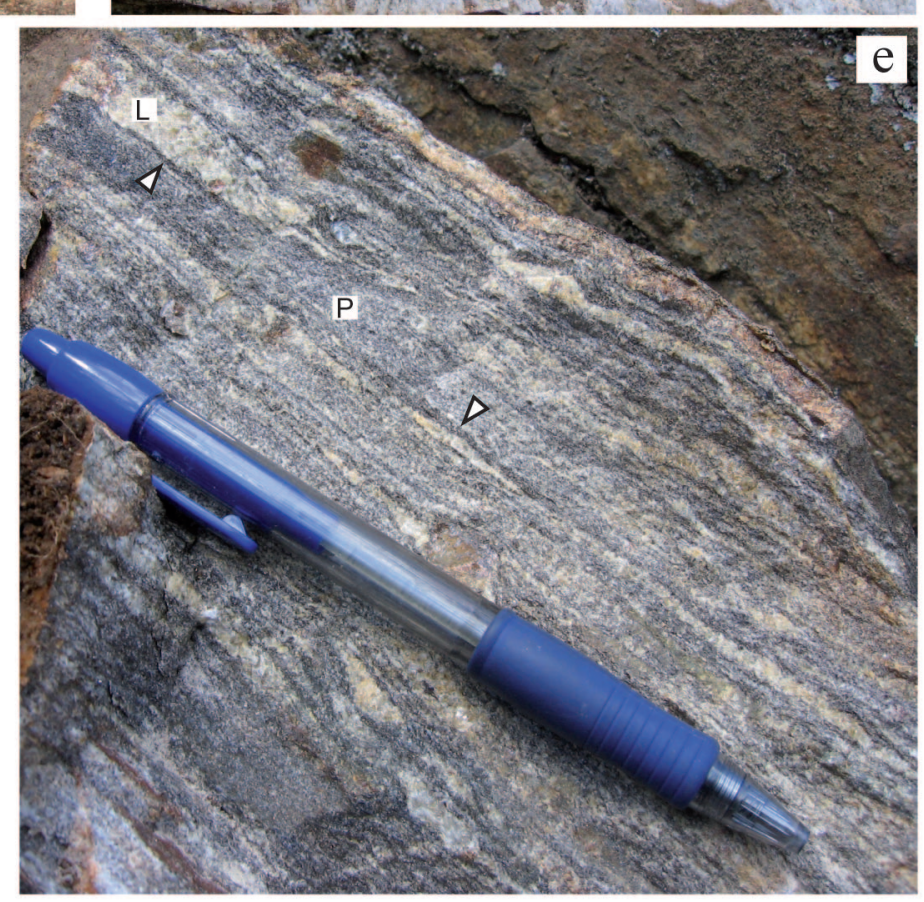
(2.

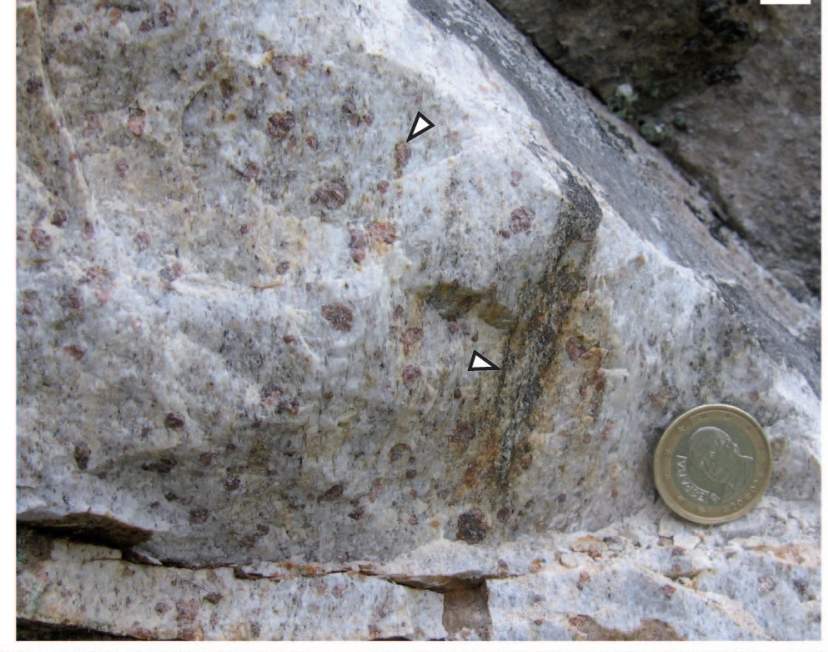

$+2 x^{2}+2$

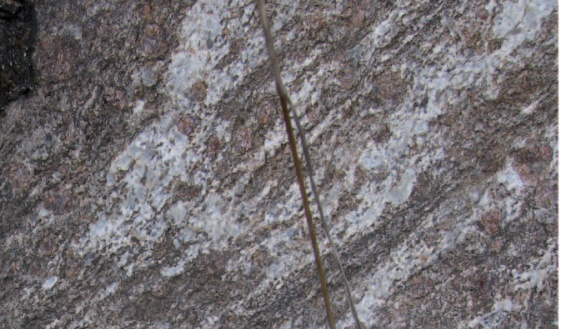

ind

$47^{12}$

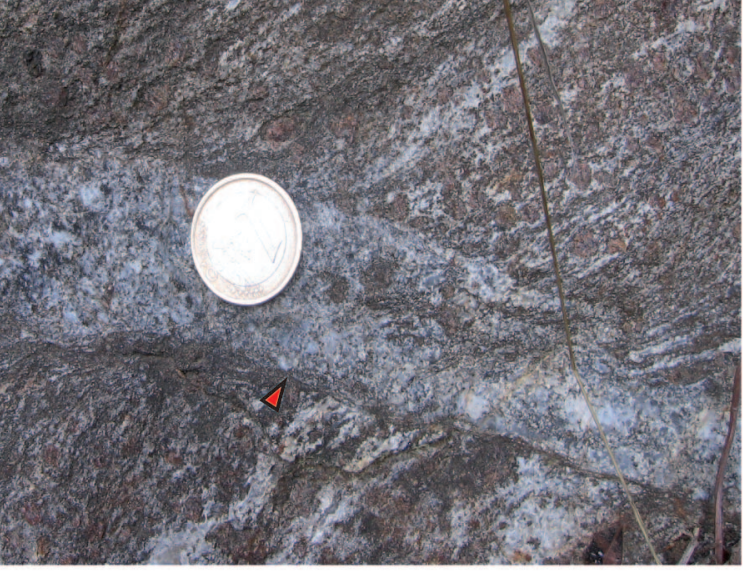

Barich et al. Fig. 2 


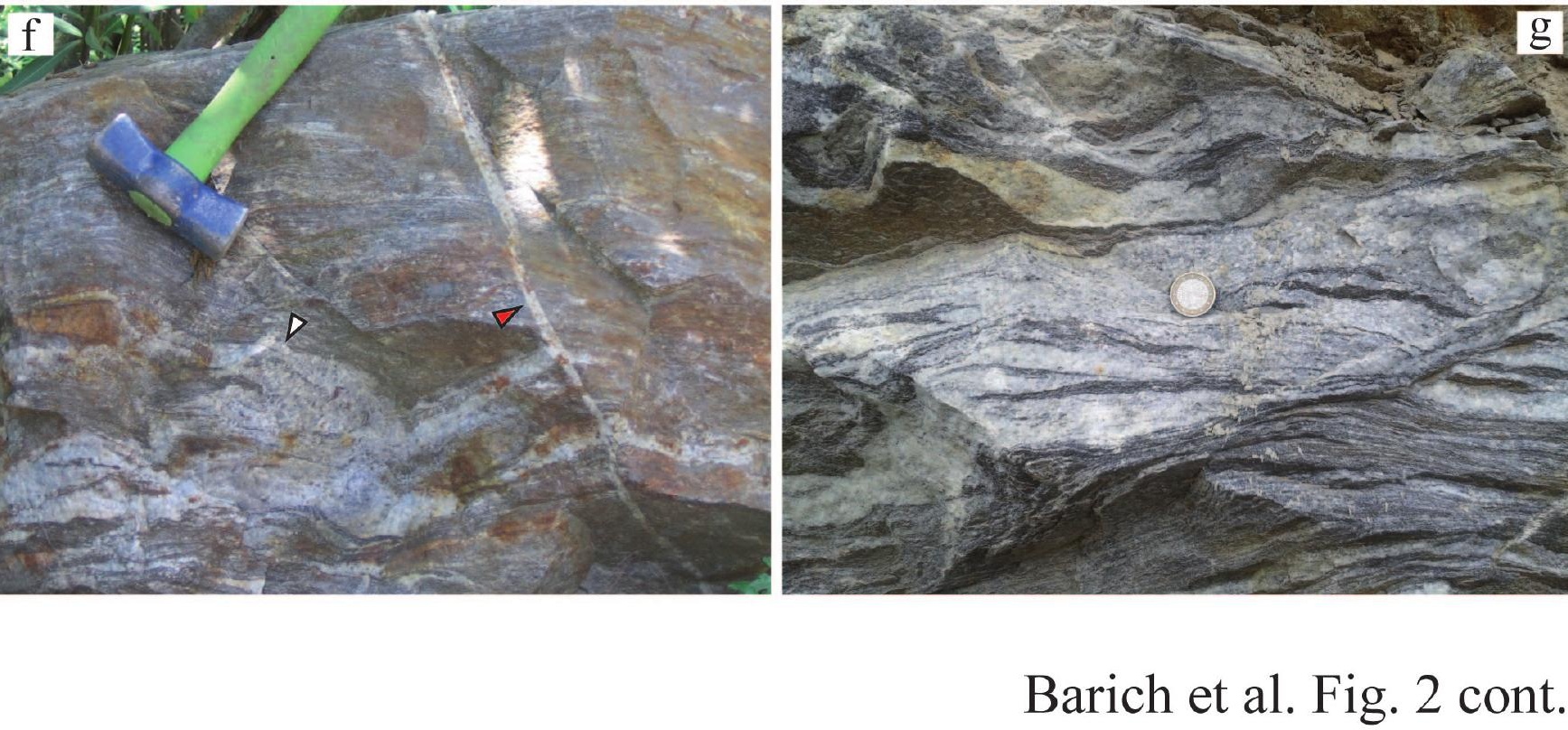




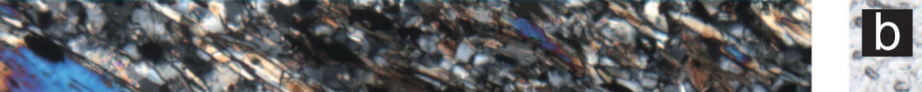

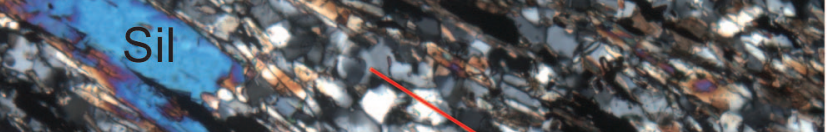

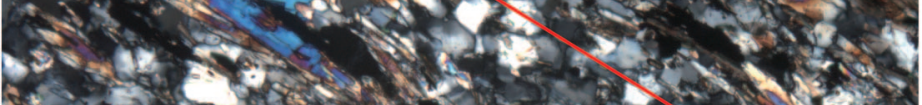

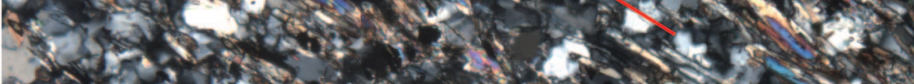
$6,7 \times 2$ ronters $160 \times 65$

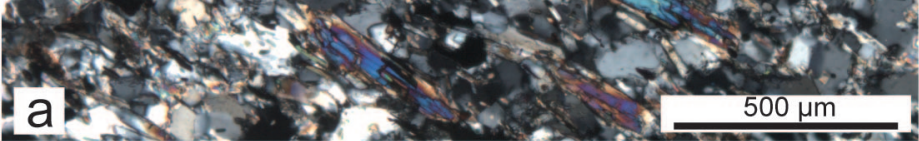
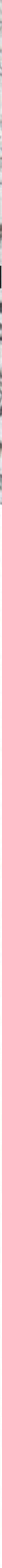
$100 \mathrm{~m}$ he 50 .

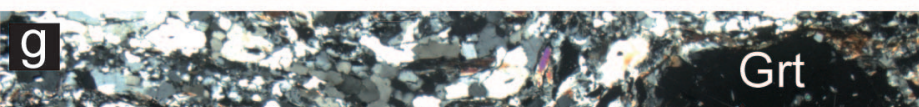
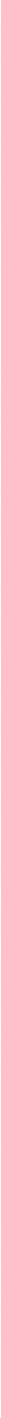

Barich et al. Fig. 4 


\section{i}

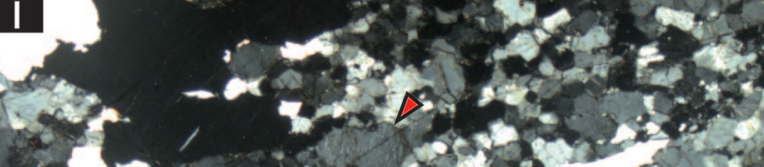

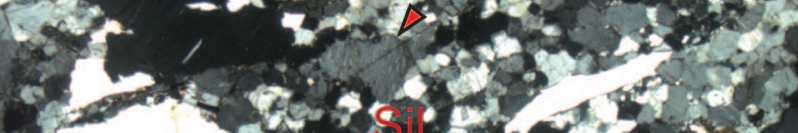

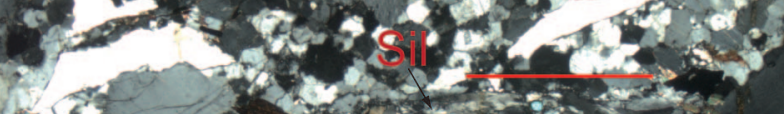

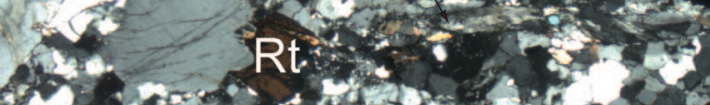

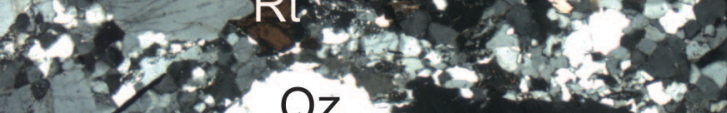
4i) $12 \mathrm{QZ}$ ?

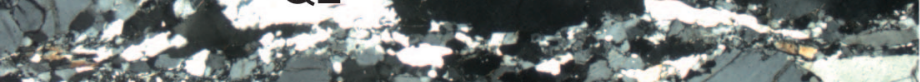

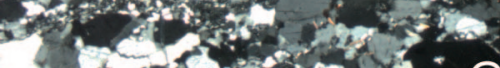

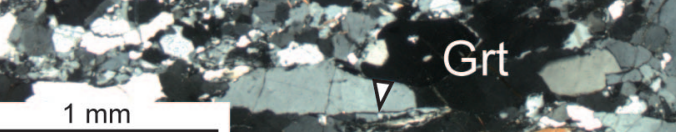
$x^{2} x^{2}$

A29:

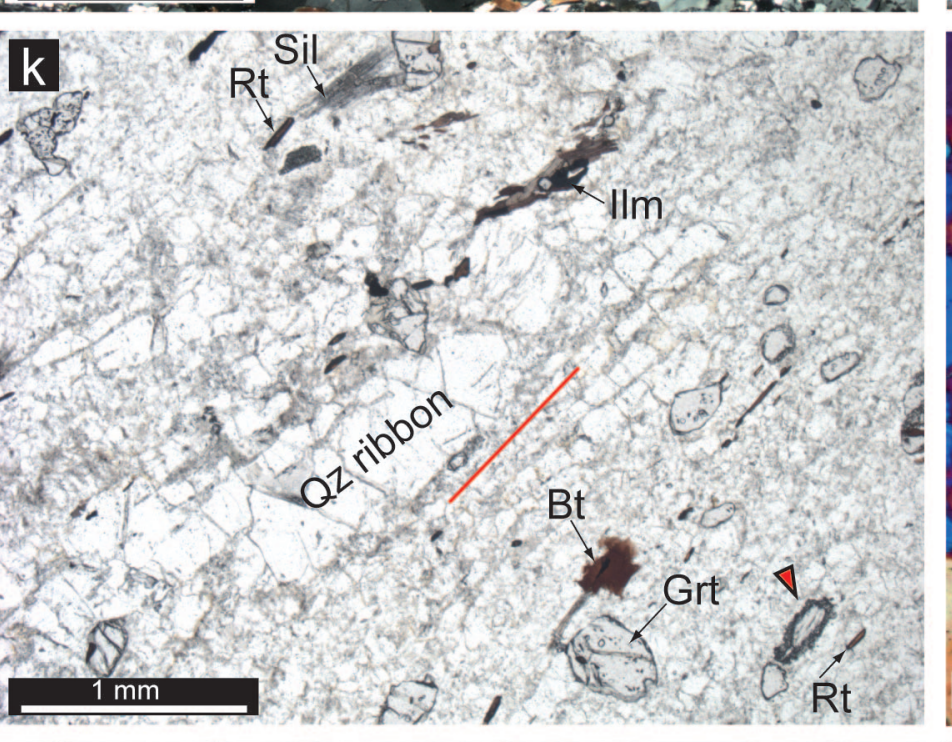

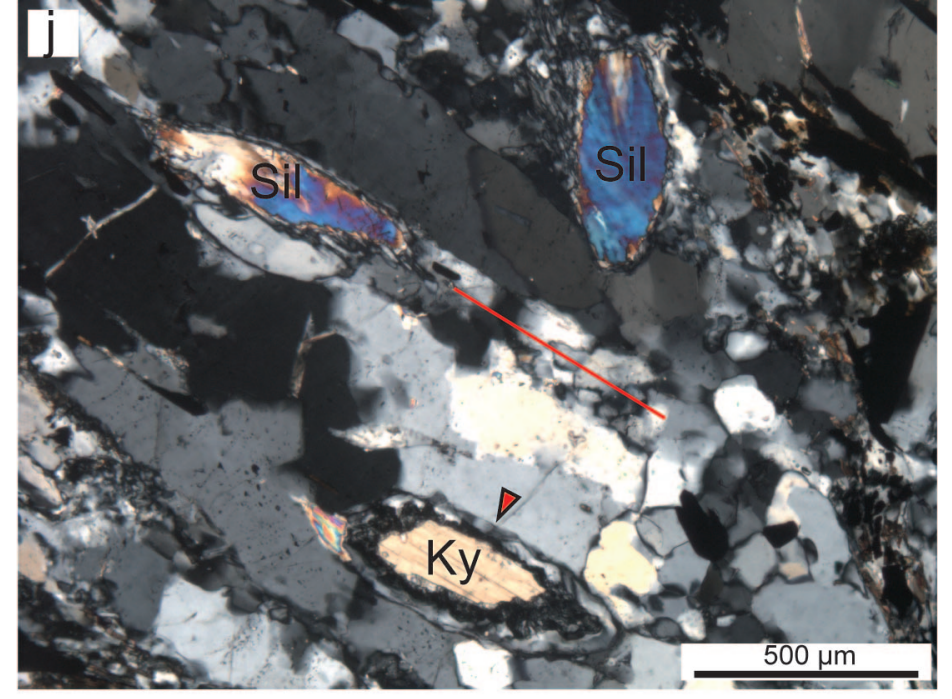

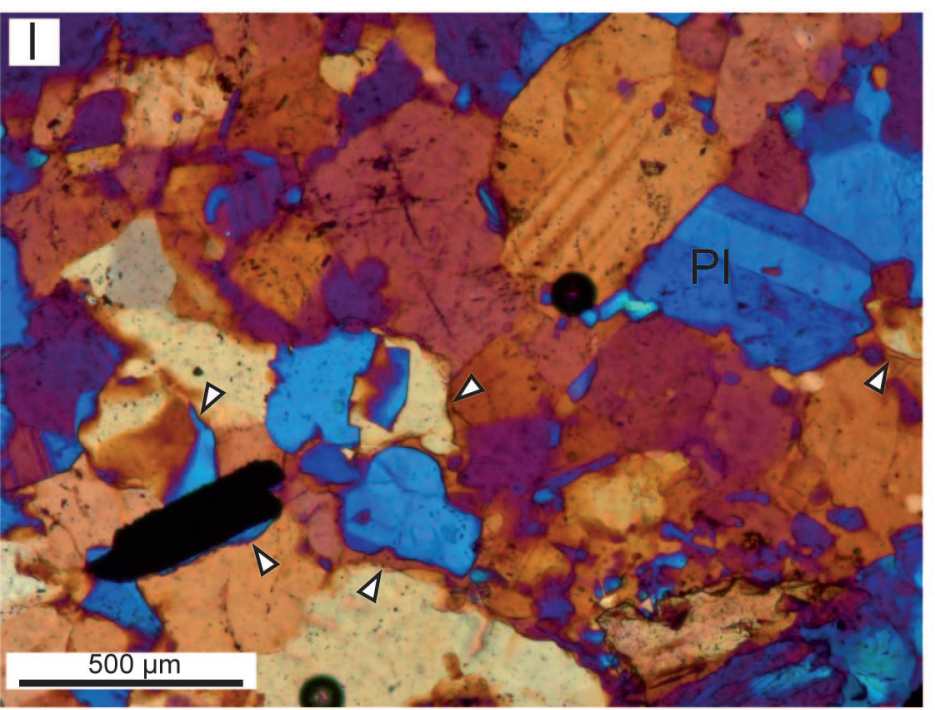

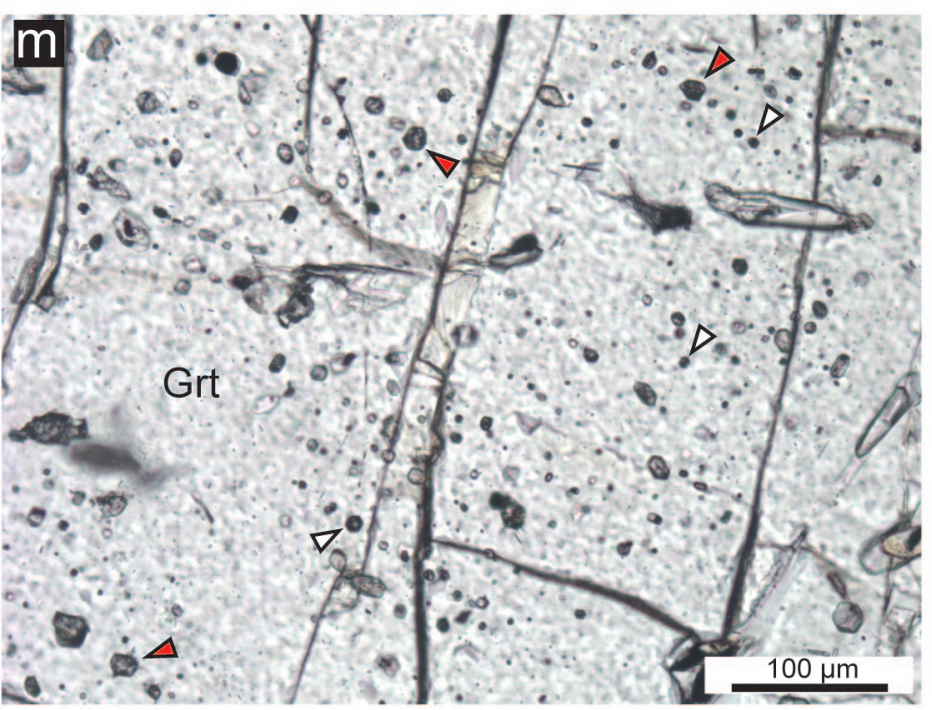

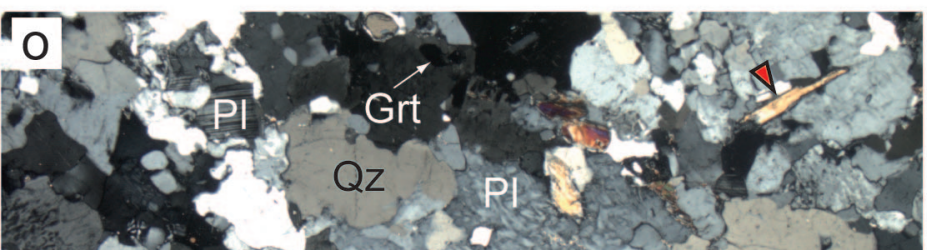

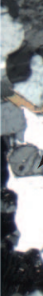
(3) 1 to 0 \% is $\sin x+2, x+2$

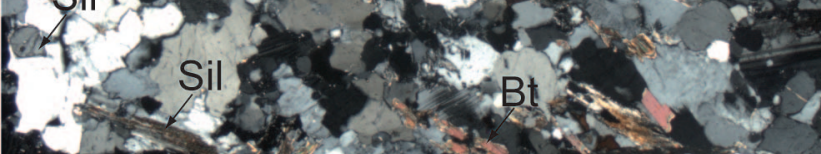

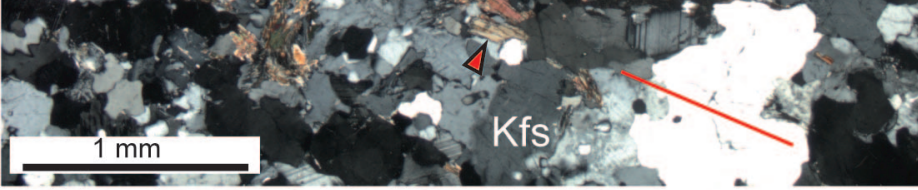

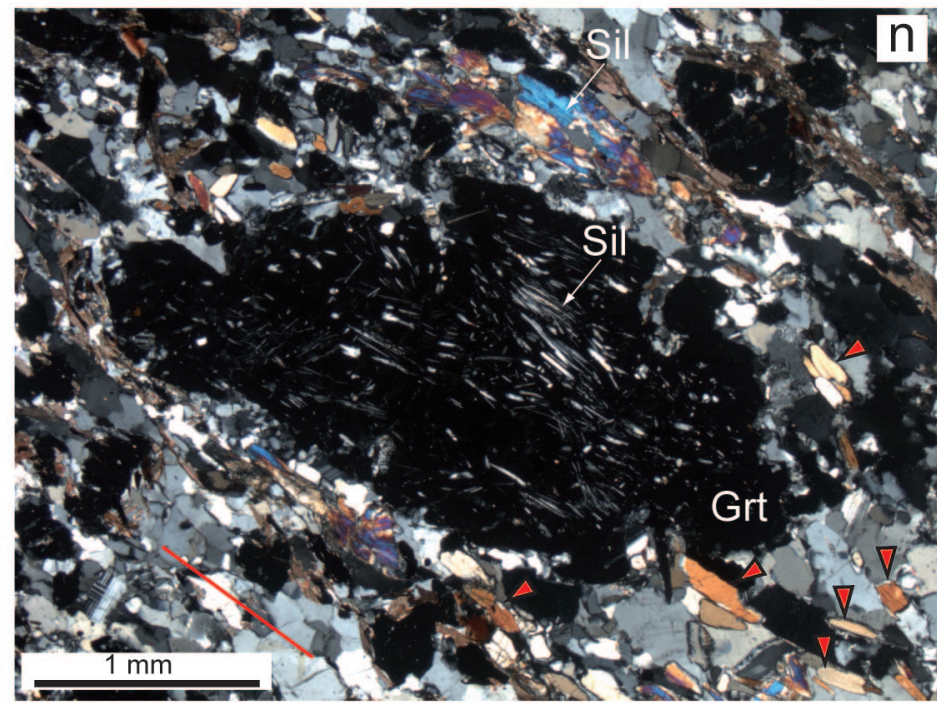

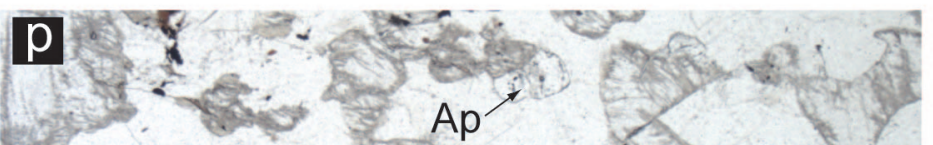

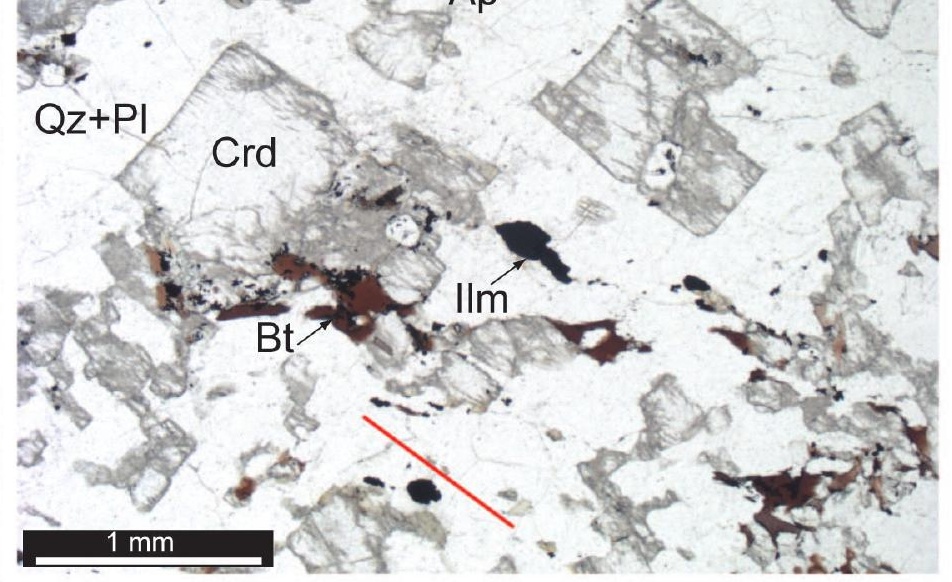

Barich et al. Fig. 4 cont. 


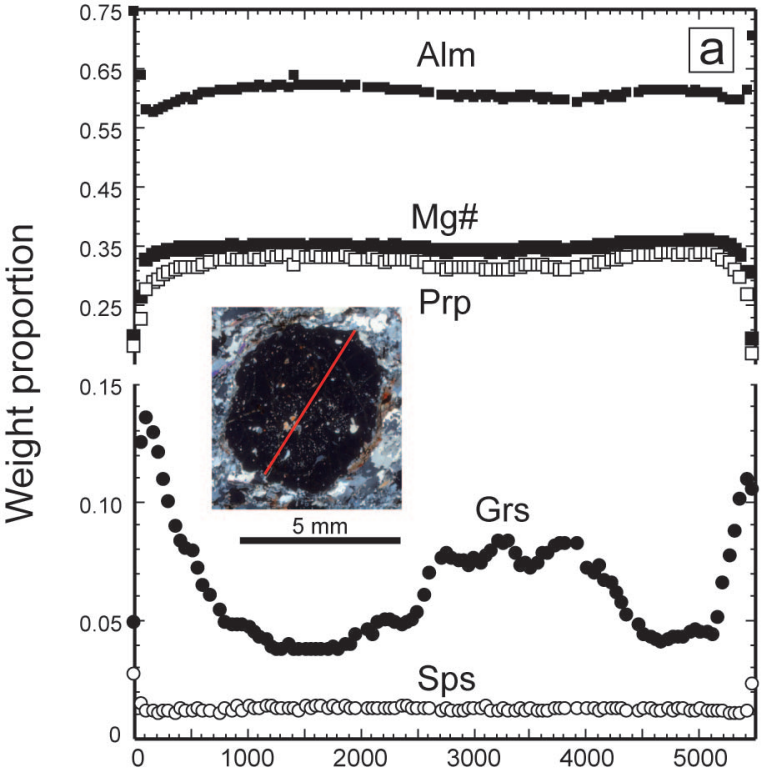

Distance to the edge (micrometers)

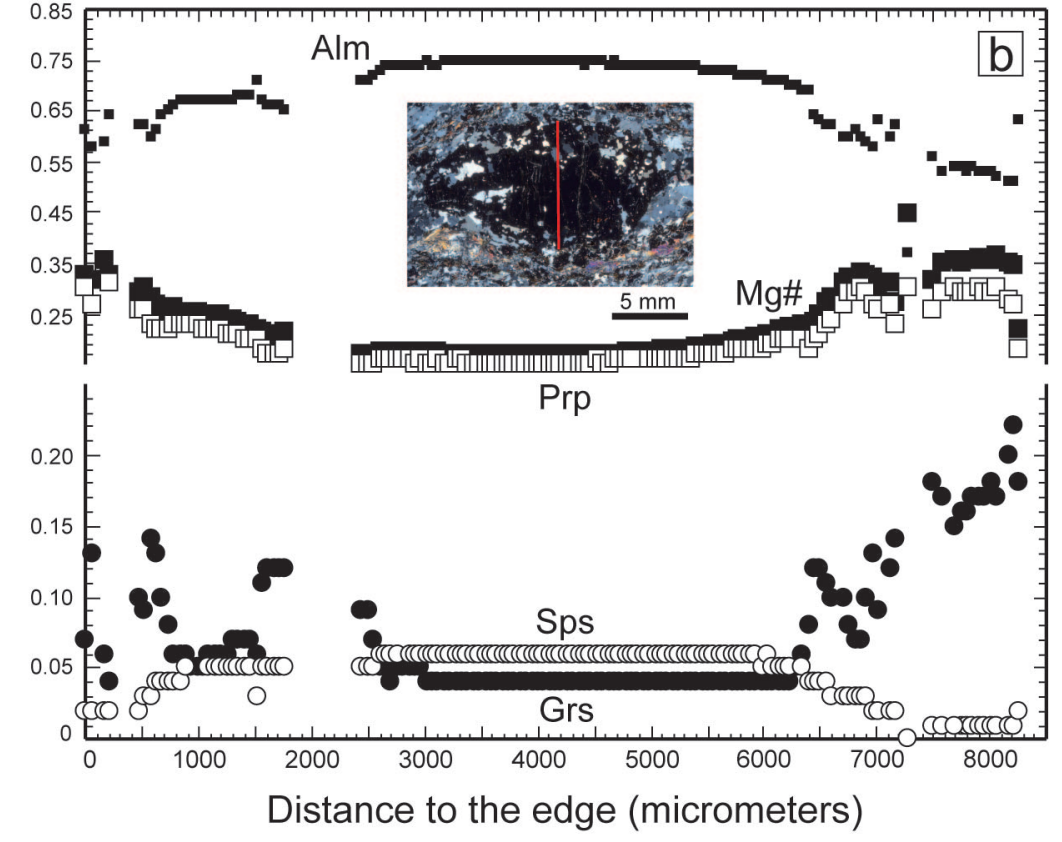

Barich et al. Fig. 5 
$a$

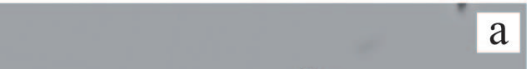

$\operatorname{Ilm} \quad \mathrm{Pl} \quad \mathrm{b}$

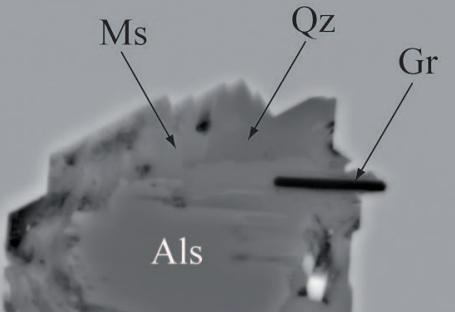

JU-16, core

Grt JU-16, core-rim

Grt

JU-16, core-rim

Grt

2/13/2013 WD Mag Spot HV Det HFW

$20 \mu \mathrm{m}$

2/13/2013 WD Mag Spot HV Det HFW $20 \mu \mathrm{m}$

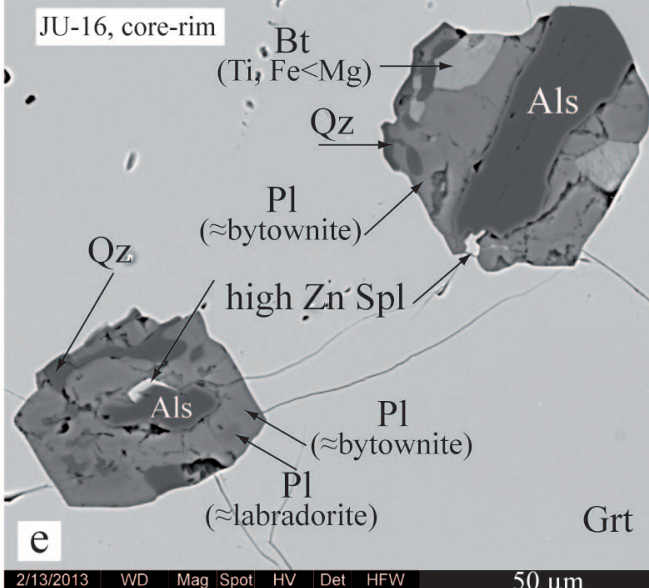

f

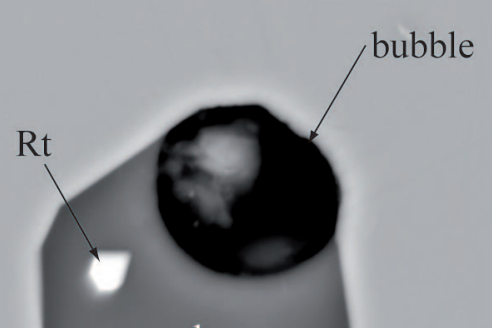

gl

JU-16, core-rim

Grt

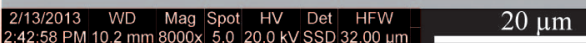

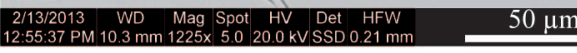
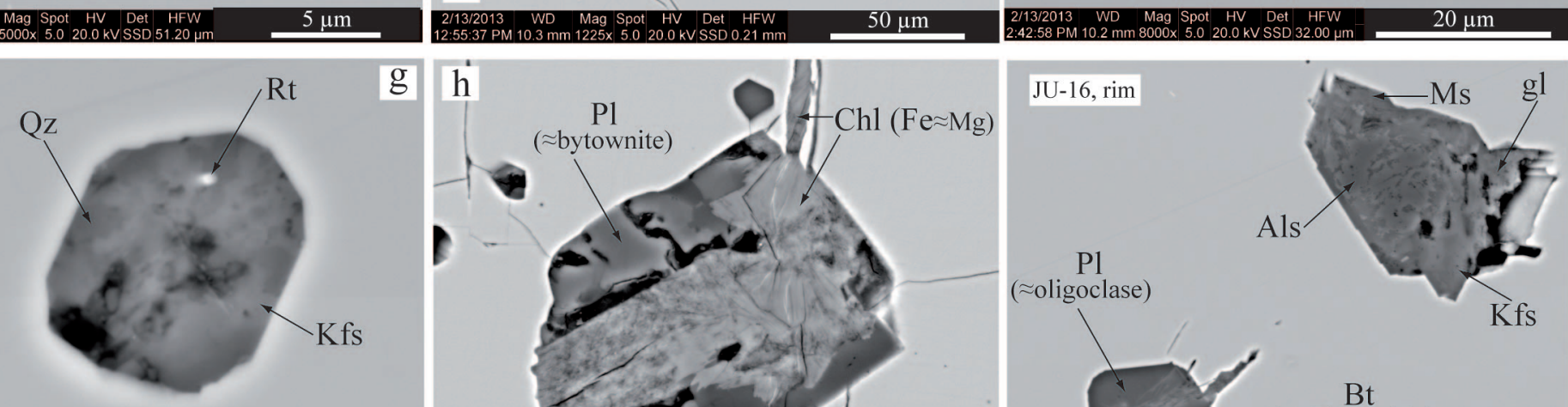

JU-16, core-rim

Grt
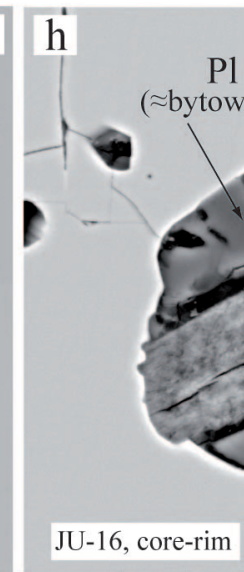

Pl
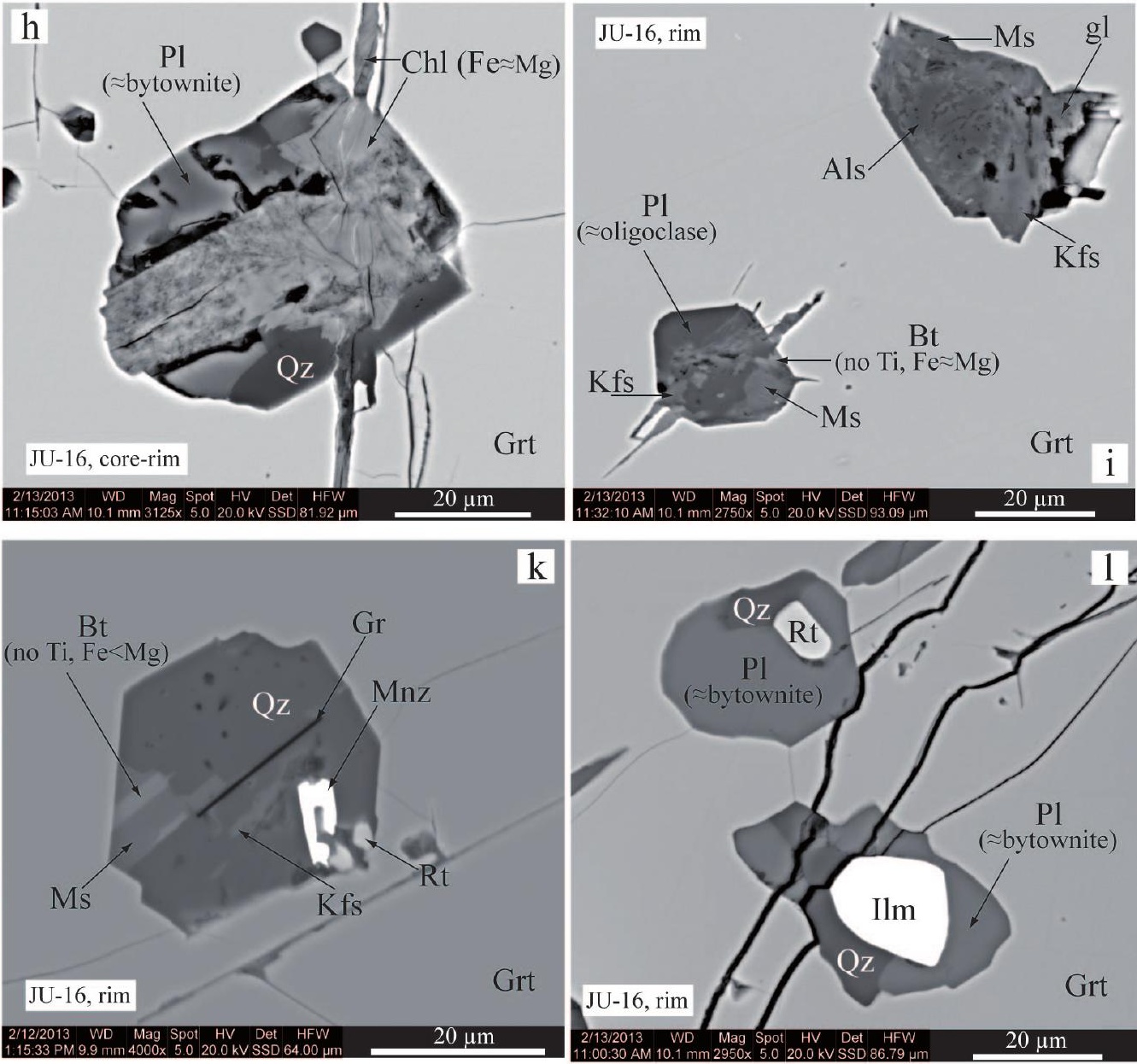

Barich et al. Fig. 7 


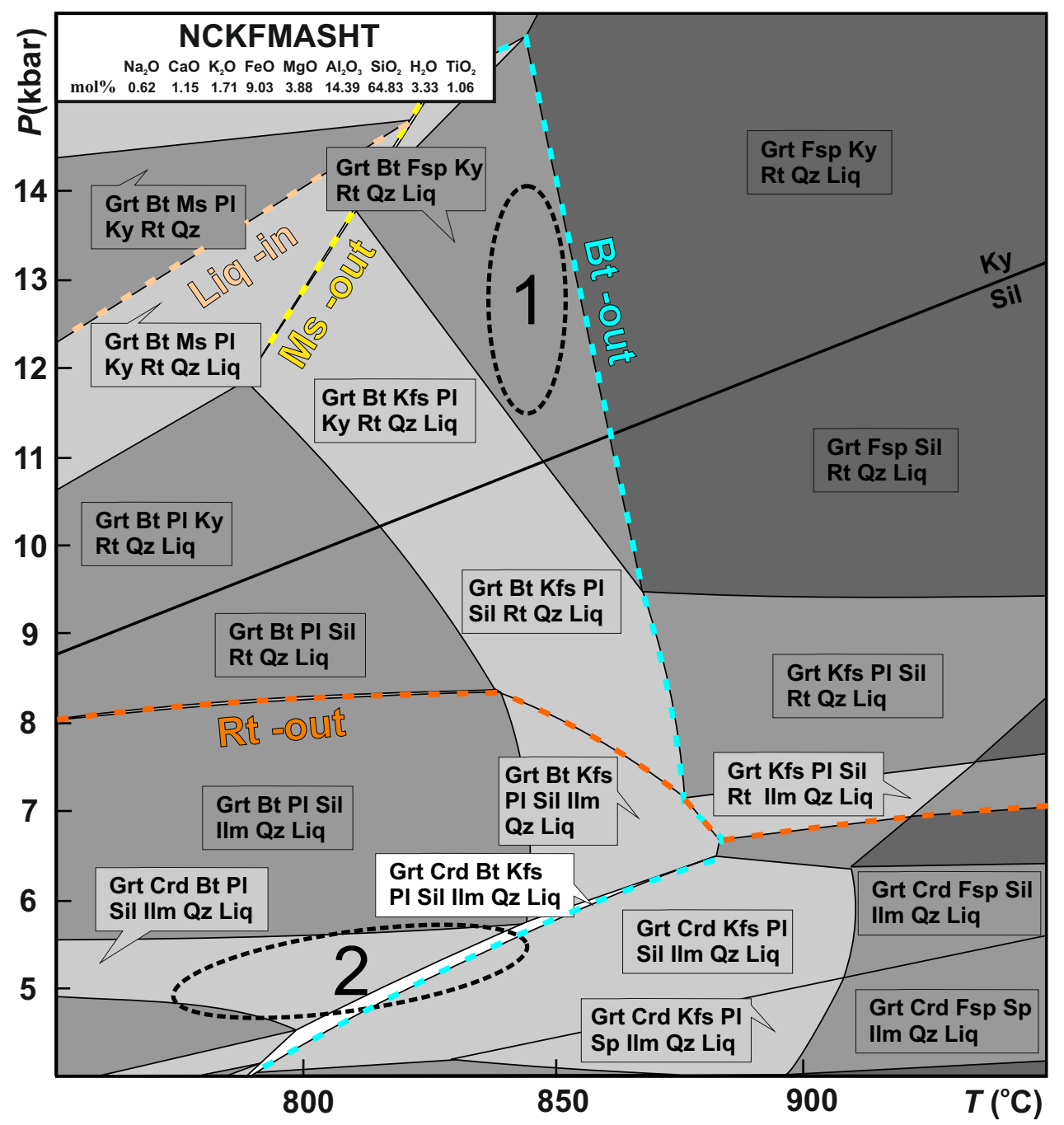


Table 1 Bulk rock composition of mylonitic gneiss JU-7, and electron microprobe analyses (wt\%) of minerals of mylonitic gneisses JU-6, JU-7 and JU-10

\begin{tabular}{|c|c|c|c|c|c|c|c|c|c|c|c|c|c|}
\hline Material & JU-7 & Grt mean & Crd & Bt inclusion & Bt matrix & Bt corona & Pl inclusion & Pl matrix & Pl corona & Kfs & Spl inclusion & Spl corona & Ilmenite \\
\hline No. analyses & 1 & 424 & 89 & 28 & 15 & 44 & 13 & 56 & 8 & 8 & 1 & 3 & 10 \\
\hline $\mathrm{SiO}_{2}$ & 57.9 & $37.69(1.31)$ & $48.75(2.29)$ & $36.55(0.96)$ & $34.96(0.62)$ & $35.21(2.01)$ & $54.39(2.09)$ & 57.84 (1.12) & $56.99(0.61)$ & $63.69(0.61)$ & 0.05 & $0.02(0.01)$ & $0.03(0.01)$ \\
\hline $\mathrm{Al}_{2} \mathrm{O}_{3}$ & 21.8 & $21.66(0.88)$ & 32.35 (1.42) & $17.09(0.91)$ & $16.31(0.29)$ & 16.17 (2.49) & $28.12(1.36)$ & $25.91(0.68)$ & $26.72(0.37)$ & $18.67(0.27)$ & 61.56 & $58.34(0.18)$ & $0.04(0.01)$ \\
\hline $\mathrm{TiO}_{2}$ & 1.27 & $0.03(0.02)$ & $0.01(0.02)$ & $4.67(0.96)$ & $5.10(0.86)$ & $5.26(1.13)$ & $0.01(0.01)$ & $0.01(0.01)$ & $0.01(0.00)$ & $0.03(0.03)$ & 0.02 & $0.09(0.05)$ & $53.38(0.56)$ \\
\hline $\mathrm{Fe}_{2} \mathrm{O}_{3}{ }^{*}$ & 10.7 & & & & & & & & & & & & \\
\hline $\mathrm{FeO}^{*}$ & & $31.23(2.44)$ & $9.10(0.86)$ & 11.68 (1.36) & $18.05(0.83)$ & 19.46 (1.79) & $0.30(0.06)$ & $0.06(0.09)$ & $0.19(0.08)$ & $0.35(0.41)$ & 23.45 & $36.18(0.32)$ & 45.78 (1.28) \\
\hline $\mathrm{MnO}$ & 0.18 & $0.69(0.23)$ & $0.10(0.02)$ & $0.02(0.02)$ & $0.05(0.04)$ & $0.04(0.02)$ & $0.01(0.01)$ & $0.01(0.01)$ & $0.01(0.01)$ & $0.01(0.00)$ & 0.07 & $0.17(0.01)$ & $0.37(0.04)$ \\
\hline $\mathrm{MgO}$ & 2.32 & 7.51 (1.49) & $7.96(0.65)$ & $14.87(1.58)$ & $10.48(0.87)$ & $9.59(0.75)$ & $0.01(0.00)$ & $0.01(0.02)$ & $0.00(0.00)$ & $0.06(0.11)$ & 8.95 & $4.60(0.10)$ & $0.66(0.25)$ \\
\hline $\mathrm{CaO}$ & 0.96 & $1.72(0.83)$ & $0.02(0.01)$ & $0.02(0.02)$ & $0.03(0.04)$ & $0.02(0.03)$ & $10.62(1.63)$ & $8.00(0.86)$ & $8.80(0.42)$ & $0.21(0.32)$ & 0.00 & $0.01(0.01)$ & $0.01(0.02)$ \\
\hline $\mathrm{Na}_{2} \mathrm{O}$ & 0.57 & $0.02(0.04)$ & $0.07(0.02)$ & $0.51(0.25)$ & $0.16(0.03)$ & $0.15(0.04)$ & $5.33(0.88)$ & $6.76(0.55)$ & $6.45(0.23)$ & $1.73(0.32)$ & 0.22 & $0.02(0.01)$ & $0.00(0.01)$ \\
\hline $\mathrm{K}_{2} \mathrm{O}$ & 2.39 & $0.02(0.13)$ & $0.03(0.01)$ & $9.03(0.37)$ & $9.37(0.19)$ & 8.89 (1.36) & $0.25(0.07)$ & $0.41(0.12)$ & $0.27(0.02)$ & $13.77(0.60)$ & 0.01 & $0.01(0.01)$ & $0.01(0.01)$ \\
\hline $\mathrm{P}_{2} \mathrm{O}_{5}$ & n.d. & n.d. & n.d. & n.d. & n.d. & n.d. & n.d. & n.d. & n.d. & n.d. & n.d. & n.d. & n.d. \\
\hline $\mathrm{Cr}_{2} \mathrm{O}_{3}$ & n.d. & $0.03(0.03)$ & $0.01(0.01)$ & $0.06(0.05)$ & $0.06(0.02)$ & $0.20(0.18)$ & $0.01(0.01)$ & $0.01(0.01)$ & $0.01(0.01)$ & $0.01(0.02)$ & 0.29 & $0.41(0.18)$ & $0.04(0.04)$ \\
\hline $\mathrm{ZnO}$ & n.d. & $0.03(0.04)$ & $0.03(0.03)$ & $0.12(0.06)$ & $0.04(0.04)$ & $0.04(0.04)$ & $0.02(0.02)$ & $0.02(0.03)$ & $0.02(0.03)$ & $0.01(0.01)$ & 5.56 & $0.57(0.14)$ & $0.05(0.04)$ \\
\hline $\mathrm{F}$ & n.d. & $0.14(0.04)$ & $0.04(0.03)$ & $1.97(1.31)$ & $1.30(0.83)$ & $1.27(0.72)$ & $0.02(0.02)$ & $0.02(0.02)$ & $0.03(0.03)$ & $0.01(0.01)$ & 0.07 & $0.15(0.03)$ & $0.26(0.03)$ \\
\hline $\mathrm{Cl}$ & n.d. & $0.01(0.01)$ & $0.01(0.01)$ & $0.04(0.03)$ & $0.04(0.03)$ & $0.03(0.02)$ & $0.01(0.01)$ & $0.01(0.01)$ & $0.00(0.00)$ & $0.01(0.01)$ & 0.00 & $0.00(0.00)$ & $0.01(0.01)$ \\
\hline LOI & 1.79 & & & & & & & & & & & & \\
\hline Total & & $100.8(1.8)$ & $98.5(0.6)$ & $96.61(1.38)$ & $95.93(1.69)$ & $96.32(0.98)$ & $99.08(0.37)$ & $99.05(0.52)$ & $99.48(0.20)$ & $98.57(0.71)$ & 100.25 & $100.56(0.53)$ & \\
\hline ASI & 4.14 & & & & & & & & & & & & \\
\hline Mg\# & 0.46 & $0.30(0.06)$ & $0.61(0.04)$ & $0.69(0.05)$ & $0.51(0.03)$ & $0.47(0.03)$ & & & & & 0.41 & $0.19(0.00)$ & \\
\hline K\# & 0.73 & & & & & & & & & & & & \\
\hline Alm & & $65.8(5.0)$ & & & & & & & & & & & \\
\hline Prp & & $28.1(5.4)$ & & & & & & & & & & & \\
\hline Grs & & $4.6(2.2)$ & & & & & & & & & & & \\
\hline Sps & & $1.5(0.5)$ & & & & & & & & & & & \\
\hline $\mathrm{Ab}$ & & & & & & & $46.9(7.7)$ & $59.0(4.3)$ & $56.0(2.1)$ & $15.9(3.0)$ & & & \\
\hline An & & & & & & & $51.7(8.0)$ & $38.7(4.4)$ & $42.4(1.9)$ & $1.0(1.7)$ & & & \\
\hline Or & & & & & & & $1.5(0.5)$ & $2.3(0.7)$ & $1.8(0.5)$ & $83.1(4.0)$ & & & \\
\hline
\end{tabular}

* Total $\mathrm{Fe}$ as $\mathrm{FeO}$ or $\mathrm{Fe}_{2} \mathrm{O}_{3}$

${ }^{a}$ Water by difference (100-EMP total) 
Table 2 Bulk rock composition of porphyroblastic gneiss JU-21, and electron microprobe analyses (wt\%) of minerals of porphyroblastic gneisses JU-21 and JU-25

\begin{tabular}{|c|c|c|c|c|c|c|c|c|c|c|}
\hline $\begin{array}{l}\text { Mineral } \\
\text { No. analyses }\end{array}$ & $\begin{array}{c}\mathrm{JU}-21 \\
1\end{array}$ & $\begin{array}{c}\text { Grt mean } \\
264\end{array}$ & $\begin{array}{c}\text { Grt core } \\
43\end{array}$ & $\begin{array}{c}\text { Grt rim } \\
62\end{array}$ & $\begin{array}{c}\text { Bt inclusion } \\
14\end{array}$ & $\begin{array}{l}\text { Bt matrix } \\
64\end{array}$ & $\begin{array}{c}\text { Bt corona } \\
2\end{array}$ & $\begin{array}{c}\text { Pl matrix } \\
94\end{array}$ & $\begin{array}{c}\text { Pl corona } \\
3\end{array}$ & $\begin{array}{c}\text { Kfs } \\
29\end{array}$ \\
\hline $\mathrm{SiO}_{2}$ & 62.5 & $36.98(0.75)$ & $36.24(0.06)$ & $37.08(1.07)$ & $34.19(0.28)$ & $34.99(0.34)$ & $34.76(0.03)$ & $55.94(0.88)$ & $52.30(1.42)$ & $63.02(0.40)$ \\
\hline $\mathrm{Al}_{2} \mathrm{O}_{3}$ & 17.7 & $21.18(0.30)$ & $20.93(0.04)$ & $21.24(0.44)$ & $17.54(0.80)$ & $16.61(0.49)$ & $15.56(0.15)$ & $26.43(0.62)$ & $28.88(0.89)$ & $18.27(0.18)$ \\
\hline $\mathrm{TiO}_{2}$ & 1.02 & $0.03(0.04)$ & $0.02(0.01)$ & $0.03(0.02)$ & $5.54(0.52)$ & $5.00(0.50)$ & $6.17(0.05)$ & $0.01(0.01)$ & $0.01(0.00)$ & $0.02(0.01)$ \\
\hline $\mathrm{Fe}_{2} \mathrm{O}_{3}{ }^{*}$ & 7.83 & & & & & & & & & \\
\hline $\mathrm{FeO}^{*}$ & & 30.18 (3.04) & $33.96(0.17)$ & $29.02(2.55)$ & $18.88(0.85)$ & $15.96(0.67)$ & $17.40(0.26)$ & $0.10(0.13)$ & $0.35(0.10)$ & $0.08(0.17)$ \\
\hline $\mathrm{MnO}$ & 0.13 & $2.02(0.97)$ & $2.64(0.07)$ & $1.48(0.76)$ & $0.07(0.02)$ & $0.03(0.02)$ & $0.02(0.01)$ & $0.01(0.02)$ & $0.01(0.01)$ & $0.01(0.01)$ \\
\hline $\mathrm{MgO}$ & 2.20 & $5.63(1.46)$ & $3.94(0.05)$ & $6.16(1.28)$ & $8.35(0.53)$ & $11.30(0.48)$ & $10.31(0.01)$ & $0.01(0.00)$ & $0.01(0.00)$ & $0.00(0.00)$ \\
\hline $\mathrm{CaO}$ & 2.16 & $3.02(1.69)$ & $1.48(0.08)$ & 3.78 (1.68) & $0.01(0.01)$ & $0.02(0.02)$ & $0.02(0.00)$ & $8.92(0.72)$ & $11.67(1.10)$ & $0.22(0.20)$ \\
\hline $\mathrm{Na}_{2} \mathrm{O}$ & 1.00 & $0.02(0.04)$ & $0.02(0.01)$ & $0.02(0.09)$ & $0.20(0.07)$ & $0.17(0.03)$ & $0.17(0.00)$ & $6.09(0.42)$ & $4.55(0.61)$ & $1.39(0.16)$ \\
\hline $\mathrm{K}_{2} \mathrm{O}$ & 3.16 & $0.02(0.03)$ & $0.01(0.01)$ & $0.02(0.05)$ & $9.20(0.21)$ & $9.24(0.16)$ & $9.20(0.00)$ & $0.32(0.08)$ & $0.21(0.04)$ & $14.15(0.33)$ \\
\hline LOI & 2.20 & & & & & & & & & \\
\hline $\mathrm{Cr}_{2} \mathrm{O}_{3}$ & & $0.02(0.02)$ & $0.02(0.02)$ & $0.03(0.03)$ & $0.05(0.03)$ & $0.06(0.03)$ & $0.14(0.04)$ & $0.01(0.01)$ & $0.01(0.02)$ & $0.01(0.01)$ \\
\hline $\mathrm{ZnO}$ & & $0.05(0.04)$ & $0.05(0.04)$ & $0.04(0.04)$ & $0.07(0.06)$ & $0.06(0.05)$ & $0.00(0.00)$ & $0.03(0.03)$ & $0.00(0.00)$ & $0.03(0.04)$ \\
\hline $\mathrm{F}$ & & $0.16(0.04)$ & $0.17(0.03)$ & $0.15(0.04)$ & $0.70(0.17)$ & $0.70(0.08)$ & $0.56(0.02)$ & $0.04(0.03)$ & $0.04(0.04)$ & $0.05(0.03)$ \\
\hline $\mathrm{Cl}$ & & $0.01(0.01)$ & $0.00(0.01)$ & $0.01(0.01)$ & $0.46(0.22)$ & $0.01(0.01)$ & $0.02(0.00)$ & $0.01(0.01)$ & $0.00(0.00)$ & $0.01(0.01)$ \\
\hline Total & & $99.30(0.88)$ & $99.47(0.17)$ & 99.04 (1.66) & $95.27(0.33)$ & $94.12(0.52)$ & $94.31(0.20)$ & $97.90(0.38)$ & $98.04(0.09)$ & $97.26(0.53)$ \\
\hline ASI & 1.97 & & & & & & & & & \\
\hline Mg\# & 0.53 & $0.25(0.07)$ & $0.17(0.00)$ & $0.28(0.06)$ & $0.44(0.02)$ & $0.56(0.02)$ & $0.51(0.00)$ & & & \\
\hline K\# & 0.67 & & & & & & & & & \\
\hline Alm & & $65.5(7.2)$ & $74.7(0.5)$ & 62.7 (5.9) & & & & & & \\
\hline Prp & & $21.7(5.5)$ & $15.3(0.5)$ & $23.7(4.7)$ & & & & & & \\
\hline Grs & & $8.3(4.6)$ & $4.1(0.4)$ & $10.4(4.6)$ & & & & & & \\
\hline Sps & & $4.5(2.2)$ & $6.0(0.2)$ & $3.4(1.6)$ & & & & & & \\
\hline $\mathrm{Ab}$ & & & & & & & & $54.2(3.5)$ & $40.7(5.0)$ & $12.8(1.5)$ \\
\hline An & & & & & & & & $43.9(3.9)$ & $57.7(5.5)$ & $1.3(0.9)$ \\
\hline Or & & & & & & & & $1.9(0.5)$ & $1.0(0.0)$ & $86.0(2.0)$ \\
\hline
\end{tabular}

* Total $\mathrm{Fe}$ as $\mathrm{FeO}$ or $\mathrm{Fe}_{2} \mathrm{O}_{3}$ 